\title{
Single entity tests in U.S. antitrust and EU competition law
}

Pieter Van Cleynenbreugel*

Competition law structures economic entities' market behaviour. The notion of economic entity potentially captures distinct corporate legal persons within a single economic enterprise. To the extent that these distinct corporate legal entities present a single entity, competition law enforcement profoundly alters in scope.

On the one hand, single entity notions provide a defense for multiple corporate entities to avoid antitrust scrutiny. On the other, they embolden competition authorities to impute fines for competition law infringements committed by subsidiaries or affiliates to parent or otherwise affiliated companies. The U.S. Supreme Court opinion in American Needle seems to have curbed enthusiasm for single entity defenses, whereas increasing reliance on parent company liability transformed EU single entity claims into powerful prosecutorial devices.

This article explores the conditions to establish successful single entity claims in U.S. antitrust and EU competition law. Both legal orders apply similar conceptions of (corporate) control and (market) conduct to determine the scope of single entity claims. In so doing, control and conduct have been operationalized in different ways, leaving significant gaps or inconsistencies in the development of a true single entity test. The juxtaposition of both single entity approaches aims to contribute to remedying those inconsistencies.

Indra Arteschene ${ }^{\dagger}$ provided immensely valuable research assistance in compiling EU competition law materials and preparing summaries for particular sections covered by this paper.

\footnotetext{
${ }^{*}$ Drs. Pieter Van Cleynenbreugel (LL.B, LL.M., University of Leuven; LL.M., Harvard University) is a Fellow of the Research Foundation Flanders and a member of the Centre for a Common Law of Europe, University of Leuven, Faculty of Law.

${ }^{\dagger}$ Indra Arteschene (LL.B., LL.M., University of Leuven) is a former research student at the Centre for a Common Law of Europe. Ms. Arteschene contributed to researching and summarizing the EU competition law sections of this paper.
} 


\section{Introduction}

Economic and legal entities do not always coincide for competition law purposes, as competition law mainly structures economic entities' behaviour. ${ }^{1}$ A single economic entity frequently comprises distinct corporate legal persons, jointly contributing to a single economic enterprise. To the extent that multiple corporate legal entities present themselves as a single economic entity, the scope of competition law enforcement alters in relation to interactions within and among those constituent legal entities. This article explores the conditions enabling competition law practitioners successfully to establish the claim that multiple corporate entities present a single entity for the purposes of competition law. These single entity claims will be discussed in light of recent developments in U.S. antitrust and EU competition law. ${ }^{2}$

The single entity concept is inherently double-edged. On the one hand, single entity claims exonerate or shield market behaviour from competition law sanctions. On the other, they also potentially extend the reach of competition law fines to related legal entities. Reliance on single entity claims allows competition authorities to include parent companies or otherwise affiliated businesses in the calculation and imputation of competition law penalties directly related to subsidiaries' behaviour. A broad 'single economic entity' conception thus enables competition authorities to sanction larger entities comprising multiple affiliated corporations. ${ }^{3}$ As such, single entity provides a defense for businesses (defensive dimension) and an enhanced 'prosecutorial' device for competition authorities (prosecutorial dimension). ${ }^{4}$

\footnotetext{
${ }^{1}$ The notion of corporate legal entity only plays a subordinate role in competition law. U.S. antitrust laws have been created to complement corporate laws in regulating market behaviour. More specifically, U.S antitrust laws were meant to address coordination and cooperation among businesses, see for an overview in that regard, $\mathrm{M}$. Horwitz, The transformation of American law 1870-1960: the crisis of legal orthodoxy (Oxford, Oxford University Press, 1992), 80-85. See also H. Hovenkamp, 'The Sherman Act and the Classical Theory of Competition', Iowa Law Review 74 (1989), 1019-1065. A similar argument can be made for EU competition law, which is pervaded by the notion of undertaking, as part three of this article will demonstrate. See also W. Wils, 'The undertaking as subject of E.C. competition law and the imputation of infringements to natural or legal persons', E.L.Rev. 25 (2000), 101-102.

${ }^{2}$ See for an earlier comparative study, G. Assant, 'Anti-trust intracorporate conspiracies: a comparative study of French, EEC and American Laws', ECLR 11 (1990), 65-79.

${ }^{3}$ A. Montesa and A. Givaja, 'When Parents Pay for their Children's Wrongs: Attribution of Liability for EC Antitrust Infringements in Parent-Subsidiary Scenarios', W. Comp. 29 (2006), 555-574; R. Burnley, 'Group Liability for Antitrust Infringements: Responsibility and Accountability’, W. Comp. 33 (2010), 595-614.

${ }^{4}$ These functions can also be related to the scope of application and the scope of imputation of competition law provisions, see W. Wils, note 1 above, 100 .
} 
The defensive dimension garnered most attention in U.S. antitrust analysis. EU law also considered single entity defenses but recent scholarly and judicial attention there is dominated by single entity prosecutions. More particularly, the liability of parent companies for competition law infringements of a subsidiary is gaining prominence among EU competition law professionals. ${ }^{5}$ The limits and possibilities of attributing competition law actions to parent companies have revitalized long held discussions on the notion of undertaking as a tool to enforce EU competition law.

Throughout these different emphases, both legal systems have struggled to develop a nuanced and generally applicable single entity framework determining the boundaries of competition law enforcement. In so doing, judges have increasingly taken notice of particular economic criteria related to control (rights), business interests and market conduct within and among different affiliated businesses. In this article, we aim to structure the case law criteria in newly proposed U.S. and EU single entity testing frameworks. We highlight that both legal systems rely on similar criteria and attach similar (but not entirely equal) weight to different conditions of control and conduct. In so doing, we aim to uncover the single entity narratives that guide EU and U.S. judges and regulators. More specifically, we aim to provide new ways of reflecting upon the EU's single entity test in light of future refining or convergence initiatives. $^{6}$

The following two parts of this paper elaborate on the different applications of single entity claims in U.S. antitrust and EU competition law. We demonstrate that both legal systems rely on similar conceptions of control and conduct to define and delineate single entity claims. The concrete applications and interrelationships among these conceptions nevertheless differ in scope and intensity. The second part sketches the rise of the single entity defense in U.S.

\footnotetext{
${ }^{5}$ K. Hofstetter and M. Ludescher, 'Fines against Parent Companies in EU Antitrust Law: Setting Incentives for 'Best Practice Compliance', W. Comp. 33 (2010), 55-76; A. Riesenkampf and U. Krauthausen, 'Liability of parent companies for antitrust violations of their subsidiaries', ECLR 31 (2010), 38-41; L. La Rocca, 'The controversial issue of the parent company liability for the violation of EC competition rules by the subsidiary', ECLR. 32 (2011), 73-74; See also references in note 3 above.

${ }^{6}$ Convergence or divergence tendencies among EU and US competition law systems have been subject to a wealth of literature, mainly focusing on extraterritoriality, differences in merger procedures, different approaches towards consumer welfare and economic efficiency etc. On differences, see among many others, G. Niels and A. Ten Kate, 'Introduction: antitrust in the U.S. and the EU - converging or diverging paths', Antitrust Bulletin 49 (2004), 1-29 for an analysis with respect to mergers. See also C.A. Jones, 'Foundations of Competition Policy in the EU and USA: conflict, convergence and beyond' in H. Ullrich, The evolution of European competition law. Whose regulation, which competition? (Cheltenham, Edward Elgar, 2006), 17-37. For a perspective from a 'global level', see D. Gerber, Global Competition. Law, Markets and Globalization (Oxford, Oxford University Press, 2010). Emphasizing antitrust convergence from a transatlantic perspective, see the casebook authored by E. Elhauge and D. Geradin, Global competition law and economics (Oxford, Hart, 2007).
} 
antitrust law and its apparent curtailment in the recent American Needle case. The third part analyzes the scope of single entity claims as engrained in the EU's undertaking concept. It distinguishes the defensive dimension from the more recent prosecutorial dimension and extracts the scope of EU single entity claims from both dimensions. A concluding fourth part argues that the notions of control and conduct require more elaboration in both legal systems to enhance the certainty and predictability of single entity tests. Mutual refinement through comparing EU and U.S. approaches provides a relevant stepping stone towards developing a full-fledged and detailed single entity test in both legal systems.

\section{Single entity claims in U.S. antitrust law}

This part discusses the state of single entity claims in U.S. antitrust law. Entities subject to antitrust investigations often claim that they present a single economic entity to which U.S. cartel prohibitions do not apply. Following a general introduction into the analytical framework of single entity claims (section 1), we discuss the seminal cases that have structured single entity debates over the last century (section 2). We subsequently argue how particular readings of these cases triggered the outcome in the 2010 American Needle judgment (section 3). That outcome provides a basis for the establishment of a nuanced U.S. antitrust single entity test (section 4).

\subsection{A matter of degree: the scope of application U.S. antitrust law}

The U.S. single entity doctrine provides business units with a defense against the imposition of antitrust penalties. Single entity claims aim to identify 'objective criteria for relieving certain types of governance structures from antitrust scrutiny'. ${ }^{7}$ The notion of single entity was most explicitly evinced in the U.S. Supreme Court's 1984 Copperweld opinion. The Supreme Court there held that a parent corporation and its wholly owned subsidiary constituted a single entity. Following divergent case law interpretations on the scope of single entity, the Supreme Court revisited and clarified its analysis in the important 2010 American Needle judgment. In order to frame both opinions and the underlying theoretical premises advocated by the Supreme Court, this section briefly sketches the concept of business unit or single entity in the analytical framework of U.S. antitrust law analysis.

\footnotetext{
${ }^{7}$ D. Williamson, 'Organization, Control and the Single Entity Defense in Antitrust', Journal of Competition Law and Economics 5 (2009), 724.
} 
The most important provisions related to single entity claims are reflected in the 1890 Sherman Antitrust Act. ${ }^{8}$ Section 1 of the Act determines that '[e]very contract, combination in the form of a trust or otherwise, or, conspiracy, in restraint of trade' is prohibited. Every 'person' or firm engaging in restraining behaviour shall be subject to criminal and administrative penalties. ${ }^{9}$ Section 1 infringements require at least bilateral action. ${ }^{10}$ Section 2 on the other hand prohibits individual 'persons' or firms to engage in monopolization. ${ }^{11}$ Monopolization transcends the scope of merely entertaining a monopoly. It rather amounts to abusing a monopolist market position. ${ }^{12}$ According to the U.S. Supreme Court, 'it is not enough that a single firm appears to "restrain trade" unreasonably, for even a vigorous competitor may leave that impression [...] In part because it is sometimes difficult to distinguish robust competition from conduct with long-run anti-competitive effects, Congress authorized Sherman Act scrutiny of single firms only when they pose a danger for monopolization'. ${ }^{13}$ The doctrine of single entity thus determines whether multiple legal entities effectively function as one person and therefore cannot conspire in violation of Section 1.

Both sections refer to 'persons', but remain silent on the scope of personhood. The other provisions of the Sherman Act are also of little help in that respect. As Section 7 states, "the word "person", or "persons", wherever used in sections 1 to 7 of this title shall be deemed to include corporations and associations existing under or authorized by the laws of either the

\footnotetext{
${ }^{8}$ Sherman Antitrust Act, July 2, 1890, 15 U.S.C. §§ 1-7.

${ }^{9}$ More specifically, every person who shall make any contract or engage in any combination or conspiracy hereby declared to be illegal shall be deemed guilty of a felony, and, on conviction thereof, shall be punished by fine not exceeding \$10,000,000 if a corporation, or, if any other person, \$350,000, or by imprisonment not exceeding three years, or by both said punishments, in the discretion of the court.

${ }^{10}$ In a 2003 U.S. Court of Appeal for the Ninth Circuit judgment, Judge Kozinski stated that Section 1, like the tango, requires multiplicity. A company cannot conspire with itself, see Freeman v. San Diego Association of Realtors, 322 F.3d, 1147; C. Sagers on the other hand argues that the reference to combinations (representing affiliated enterprises and joint ventures) calls into question the plurality requirement of Section 1, see C. Sagers, 'American Needle, Dagher and the Evolving Antitrust Theory of the Firm: What will become of Section 1?', TheAntitrustSource 2009, 8. On plurality, see also G. Feldman, 'The Puzzling Persistence of the Single Entity Argument for Sports Leagues: American Needle and the Supreme Court's Opportunity to Reject a Flawed Defense', Wisconsin Law Review (2009), 841.

${ }^{11}$ It reads that '[e]very person who shall monopolize, or attempt to monopolize, or combine or conspire with any other person or persons, to monopolize any part of the trade or commerce among the several States, or with foreign nations, shall be deemed guilty of a felony, and, on conviction thereof, shall be punished by fine not exceeding $\$ 100,000,000$ if a corporation, or, if any other person, $\$ 1,000,000$, or by imprisonment not exceeding 10 years, or by both said punishments, in the discretion of the court'.

12 See in that regard the 1945 Second Circuit Court of Appeals opinion in United States v. Aluminum Corporation of America (Alcoa), 148 F2.d, 431. For an overview, see H. Hovenkamp, 'The Monopolization Offense', Ohio State Law Journal 61 (2000), 1035-1049; for a more critical perspective, E. Elhauge, 'Defining Better Monopolization Standards', Stanford Law Review 56 (2003), 253 - 344.

${ }^{13}$ U.S. Supreme Court, Copperweld Corporation v. Independence Tube Corporation (1984), 104 S. Ct. 2739 (hereafter referred to as Copperweld).
} 
United States, the laws of any of the Territories, the laws of any State, or the laws of any foreign country'. The extent to which multiple corporations present a single person or entity remains unclear from that reading. It was left to the courts to decide whether a contract, combination or conspiracy was concluded by multiple 'persons' or whether multiple corporations could constitute a single 'person' for antitrust enforcement purposes.

From that limited textual perspective, single entity claims address the issue 'whether an arrangement is a contract, combination, or conspiracy ${ }^{14}$ by assessing whether or not at least two 'persons' are involved. That issue, according to Justice John Paul Stevens, 'is different from and antecedent to the question whether it unreasonably restrains trade'. ${ }^{15}$

Despite this apparent antecedence of 'personhood' questions, the courts have never embraced a formal distinction between scope of application and restraints of trade analyses. On the contrary, judges subjected the single entity question to classical antitrust analysis. The U.S. Supreme Court ${ }^{16}$ has applied a classical antitrust analytical framework to single entity claims. That framework distinguishes per se, rule of reason and 'quick look' rule of reason analysis. For clarity's sake, we briefly restate these typologies of antitrust analysis, as they are determinative in the reconstruction of the U.S. single entity test.

Judicial analysis has mainly focused on the scope of analysis following which particular restraints to competition should be prohibited. Per se prohibitions are distinguished from rule of reason analyses. Per se prohibitions present an automatic rule of illegality. ${ }^{17}$ Activities that trigger a per se prohibition are immediately and without conducting a detailed (economic) analysis considered to be illegal and prohibited. They are 'so plainly anticompetitive that no elaborate study of the industry is needed to establish their illegality ${ }^{18}$. Well-known classical examples are direct price fixing and direct output limitations through cartels. ${ }^{19}$ In principle,

\footnotetext{
${ }^{14}$ U.S. Supreme Court, American Needle, Inc. v. National Football League (2010), 130 S. Ct. 2206 (hereafter referred to as American Needle).

${ }^{15}$ American Needle, note 14 above, 2206.

${ }^{16}$ Hereafter referred to as Supreme Court.

17 Automatic illegality was used by B. Jones and J. Turner, 'The Fall of the Per Se Vertical Price Fixing Rule', Journal of Legal, Ethical and Regulatory Issues 13 (2010), 84.

${ }^{18}$ U.S. Supreme Court, National Society of Professional Engineers v. United States (1978), 98 S. Ct. 1366 (hereafter referred to as Engineers).

${ }^{19}$ Bid rigging could also be included in that list. For a very succinct overview of issues, see S. Adkins, 'Too Much Competition: The Supreme Court Sacks the NFL's Single Entity Defense 9-0 in American Needle, Inc. v. National Football League', Willamette Sports Law Journal 8 (2011), 25. For a case law overview, see H. Hovenkamp, Federal Antitrust Policy. The Law of Competition and its Practice (St. Paul, Thomson, 2005), 253265 , arguing that per se rules are the result of experience, rather than logic. Courts find practices so commonly anticompetitive that they do not need to conduct an elaborate analysis to verify anticompetitiveness.
} 
per se prohibitions establish conclusive presumptions of illegality; they cannot be rebutted by procompetitive justifications adduced by parties to an agreement. ${ }^{20} \mathrm{Per}$ se analysis could also exempt particular situations from antitrust scrutiny. ${ }^{21}$ In those instances, a particular situation triggers the non-application of antitrust provisions. Per se prohibitions and exemptions thus avoid 'the necessity for an incredibly complicated and prolonged economic investigation into the entire history of the industry involved, as well as related industries, in an effort to determine at large whether a particular restraint has been unreasonable'. ${ }^{22}$

The U.S. Supreme Court limits the establishment of per se prohibitions and exemptions to exceptional situations. In most instances, the courts prefer a balance among procompetitive and anticompetitive arguments in a rule of reason analysis. The rule of reason allows the parties to present a balanced argument in which reasonable limitations on competition can be justified. ${ }^{23}$ Attention is paid to the analysis of the 'facts peculiar to the business, the history of the restraint, and the reasons why it was imposed. In either event, the purpose of the analysis is to form a judgment about the competitive significance of the restraint'. ${ }^{24}$ As long as procompetitive justifications outweigh anticompetitive consequences, the potentially anticompetitive agreement will not be condemned, unless the opposite party argues that a less restrictive alternative is available. ${ }^{25}$ Rule of reason analysis imposes particular obligations on the parties to the antitrust proceedings to provide courts with economic and substantive analyses that allow judges to make a reasonable determination of the considered practices' scope. $^{26}$

\footnotetext{
${ }^{20}$ D. Bailey, 'Presumptions in EU competition law', ECLR 31 (2010), 364.

${ }^{21}$ P. Nealis, 'Per Se Legality: A New Standard in Antitrust Adjudication under the Rule of Reason', Ohio State Law Journal 61 (2000), 347 - 398.

${ }_{22}^{22}$ U.S. Supreme Court, Northern Pacific Railway Co. v. United States (1958), 78 S. Ct. 518.

${ }^{23}$ According to Justice Brandeis famous exposition of rule of reason, the true test of legality is whether the restraint imposed is such as merely regulates and perhaps thereby promotes competition or whether it is such as may suppress or even destroy competition. To determine that question the court must ordinarily consider the facts peculiar to the business to which the restraint is applied; its condition before and after the restraint is imposed; the nature of the restraint and its effect, actual or probable. The history of the restraint, the evil believed to exist, the reason for adopting the particular remedy, the purpose or end sought to be attained are all relevant facts. This is not because a good intention will save an otherwise objectionable regulation or the reverse; but because knowledge of intent may help the court to interpret facts and to predict consequences. U.S. Supreme Court, Chicago Board of Trade of City of Chicago v. United States (1914), 34 S. Ct. 244.

${ }^{24}$ Engineers, note 18 above, 1365.

${ }^{25}$ H. Hovenkamp, note 19 above, 260; G. Feldman, 'The Misuse of the Less Restrictive Alternative Inquiry in Rule of Reason Analysis', American University Law Review 58 (2009), 561 - 630.

${ }^{26}$ S. Adkins, supra note 19 above, 24-25.
} 
'The courts have always realized that the line between the per se rule and the rule of reason is not as hard or as easy to locate as we might wish'. ${ }^{27}$ In a specific number of cases, the U.S. Supreme Court allowed a superficial analysis of seemingly anticompetitive agreements through the application of a 'quick look' or truncated rule of reason test. ${ }^{28}$ 'Quick look' presents an analytical compromise between the per se and rule of reason approaches and allows for an efficient method of managing antitrust litigation that can otherwise become overly complex. ${ }^{29}$ In cases where the anticompetitive effects on consumers and markets can be determined by someone with a basic knowledge of economics, competitive harm is presumed. ${ }^{30}$ The defendant will have to prove that procompetitive justifications nevertheless exist in such a case. ${ }^{31}$ Whereas a quick look does not amount to a non-rebuttable per se prohibition or exemption, the factual rule of reason analysis remains rather limited. The courts basically apply a rule of reason analysis, but truncate its scope because of particular properties inherent in anticompetitive behaviour. ${ }^{32}$ The extent of truncated or quick look rule of reason nevertheless remains open and contested. ${ }^{33}$

\subsection{From rule of reason intra-enterprise conspiracy to per se single entity.}

Single entity claims have thus been considered in light of the abovementioned per se/rule of reason/quick look trichotomy. Early Sherman Act case law did not address the problem of single entity. The existence of multiple conspiring entities was often taken for granted or at least not questioned. ${ }^{34}$ Only in a 1947 case, U.S. v. Yellow Cab, the Supreme Court was directly confronted with what would later be termed a single entity claim. In that case, the Supreme Court held that "corporate interrelationships of conspirators are not determinative of the applicability of the Sherman Act'. ${ }^{35}$ According to the Court, a section 1 restraint 'may

\footnotetext{
${ }^{27}$ H. Hovenkamp, note 19 above, 265.

${ }^{28}$ See blown rule of reason inquiry. See U.S. Supreme Court, National Collegiate Athletic Assn. v. Board of Regents of Univ. of Okla.(1984), 104 S.Ct. 2948, stating that the Rule of Reason can sometimes be applied in the twinkling of an eye; U.S. Supreme Court, Federal Trade Commission v. Indiana Federation of Dentists (1986), 106 S. Ct. 2018.

${ }^{29}$ E. Grush and C. Korenblit, "American Needle and a "positive" quick look approach in challenges to joint ventures', Antitrust 25 (2011), 55.

${ }^{30}$ S. Adkins, note 19 above, 25.

${ }^{31}$ U.S. Supreme Court, California Dental Association v. FTC (1999), 119 S. Ct. 1618. The Court refers to 'an intuitively obvious inference of anticompetitive effect'.

${ }^{32}$ H. Hovenkamp, note 19 above, 265.

${ }^{33}$ As apparent from E. Grush and C. Korenblit, note 29 above, 57.

${ }^{34}$ Sagers claims that early case law considered $\S 1$ and $\$ 2$ to be interchangeable. See C. Sagers, 'Why Copperweld Was Actually Kind of Dumb: Sound, Fury, and the Once and Still Missing Antitrust Theory of the Firm', forthcoming 17 Villanova Sports and Entertainment Law Journal 2011, electronic copy available at http://papers.ssrn.com/sol3/papers.cfm?abstract_id=1767339, at p. 6.

${ }^{35}$ U.S. Supreme Court, United States v. Yellow Cab Co.(1947), 67 S. Ct. 1565.
} 
result as readily from a conspiracy among those who are affiliated or integrated under common ownership as from a conspiracy of those who are otherwise independent'. ${ }^{36}$ The Supreme Court established its intra-enterprise conspiracy doctrine, holding that a single economic entity could not prima facie escape the antitrust provisions.

As a result of Yellow Cab, intra-enterprise agreements were to be assessed following a rule of reason analysis, balancing their competitive effects. In so doing, particular categories of intraenterprise or intra-entity agreements were held to escape antitrust scrutiny because of procompetitive advantages. Agreements between employers and employees and between nonincorporated branches or divisions of a corporation were held not to be covered by antitrust prohibitions. ${ }^{37}$ The Supreme Court formally extended that exemption in its 1962 Sunkist opinion, arguing that some organizational distinctions between different undertakings only bear limited meaning and effects relevant for antitrust law analysis. ${ }^{38}$

A balanced and reasonable analysis of intra-enterprise agreements nevertheless continued to dominate judicial discourse. Renowned antitrust scholars severely criticized the rule of reason approach in Yellow Cab as a waste of time and means devoted to issues that raised no antitrust concerns. According to Philip Areeda, '[m]aking liability depend on separate incorporation of units within a corporate family would introduce an altogether fortuitous element into antitrust law. The conventional reasons for separate incorporation bear little relation to a corporate family's ability or willingness to behave anticompetitively, ${ }^{39}$ From that perspective, the mere dilution of entrepreneurial functions into different corporate entities should not trigger the application of antitrust law provisions to intra-enterprise conduct not normally subject to antitrust scrutiny.

\footnotetext{
${ }^{36}$ U.S. Supreme Court, United States v. Yellow Cab Co. (1947),67 S. Ct. 1565. For similar arguments, see among others U.S. Supreme Court, Schine Chain Theatres, Inc. v. United States (1948), 68 S. Ct. 947; U.S. Supreme Court, United States v. Griffith (1948), 68, S. Ct. 941; U.S. Supreme Court, Kiefer-Stewart Co. $v$. Joseph E. Seagram \& Sons, Inc. (1951), 71 S. Ct. 259-261; U.S. Supreme Court, Timken Roller Bearing Co. v. United States (1951), 71 S. Ct. 971; U.S. Supreme Court, Perma Life Mufflers, Inc. v. International Parts Corp. (1968), 88 S. Ct. 1981.

${ }^{37}$ The U.S. Supreme Court did not directly confirm this stance, but refused to hear appellate court cases that established these claims. For an overview, we refer to the Court's own citations in Copperweld, note 13 above, 2741.

${ }^{38}$ U.S. Supreme Court, Sunkist Growers, Inc. v. Winckler \& Smith Citrus Products Co.(1962), 82 S. Ct. 1136; U.S. Supreme Court, United States v. Citizens \& Southern National Bank (1971), 95 S.Ct. 2099.

${ }^{39}$ P. Areeda, 'Intraenterprise conspiracy in decline', Harvard Law Review 97 (1981), 453.
} 
The 1984 Copperweld opinion sided with the Yellow Cab critics. Copperweld directly concerned the question whether a parent company and its wholly owned subsidiary are legally capable of conspiring with each other under section 1 of the Sherman Act. ${ }^{40}$ A corporation, Copperweld, and its wholly owned subsidiary Regal Tube Co. had purportedly agreed on limiting market access for Independence Tube Co., a potential competitor. ${ }^{41}$ In light of the Yellow Cab case law, the intra-enterprise agreement between Copperweld and Regal had to be assessed under a rule of reason framework. In its majority opinion ${ }^{42}$, the Supreme Court nevertheless claimed that in previous cases, the U.S. Supreme Court had acquiesced in the intra-enterprise conspiracy doctrine without exploring or analyzing in detail the justifications for such a rule. ${ }^{43}$ According to the Court, 'nothing in the literal meaning of those terms excludes coordinated conduct among officers or employees of the same company. But it is perfectly plain that an internal agreement to implement a single, unitary firm's policies does not raise the antitrust dangers that $\S 1$ was designed to police. The officers of a single firm are not separate economic actors pursuing separate economic interests [...]. Coordination in a firm is as likely to result from an effort to compete as from an effort to stifle competition' ${ }^{44}$ By analogy, coordination among a corporation and its unincorporated divisions also must be judged as the conduct of a single actor. ${ }^{45}$ The Supreme Court reasoned that '[f]or similar reasons, the coordinated activity of a parent and its wholly owned subsidiary must be viewed as that of a single enterprise for purposes of $\S 1$ of the Sherman Act'. ${ }^{46}$ A parent and its wholly owned subsidiary have a complete unity of interest, having common objectives and one corporate consciousness. They are 'not unlike a multiple team of horses drawing a vehicle under the control of a single driver'. ${ }^{47}$ As a parent and a wholly owned subsidiary always have a unity of purpose or a common design, the very notion of agreement in Sherman Act terms lacks meaning in this context ${ }^{48}$ : 'The parent may assert full control at any moment if the subsidiary fails to act in the parent's best interests'. ${ }^{49}$ The Court subsequently addressed the argument that this interpretation might highlight so-called gaps in the application of

\footnotetext{
${ }^{40}$ Copperweld, note 13 above, 2734.

${ }^{41}$ For a more detailed summary, see J. Stone and J. Wright, 'Antitrust Formalism is Dead! Long Live Antitrust Formalism! Some implications of American Needle v. NFL', Cato Supreme Court Review (2010), 374.

${ }^{42}$ Six justices joined Chief Justice Burger in his opinion. Justice John Paul Stevens filed a dissenting opinion, joined by Justices Brennan and Marshall.

${ }_{43}$ Copperweld, note 13 above, 2739.

${ }^{44}$ Copperweld, note 13 above, 2740.

${ }^{45}$ Copperweld, note 13 above, 2741.

${ }^{46}$ Copperweld, note 13 above, 2741.

${ }^{47}$ Copperweld, note 13 above, 2741-2742.

${ }^{48}$ Copperweld, note 13 above, 2742.

${ }^{49}$ Copperweld, note 13 above, 2742.
} 
competition law provisions. 'Because the Sherman Act does not prohibit unreasonable restraints of trade as such [...], it leaves untouched a single firm's anticompetitive conduct (short of threatened monopolization) that may be indistinguishable in economic effect from the conduct of two firms subject to $\S 1$ liability.[...] Congress made a purposeful choice to accord different treatment to unilateral and concerted conduct. Had congress intended to outlaw unreasonable restraints as such, $\S 1$ 's requirement of a contract, combination or conspiracy would be superfluous, as would the entirety of $\S 2,{ }^{50}$ The Supreme Court could therefore only conclude that the coordinated behaviour of a parent and its wholly owned subsidiary falls outside the reach of section $1 .^{51}$

\subsection{American Needle and the retreat from per se single entity}

\subsubsection{Copperweld's per se puzzle}

The Copperweld opinion vindicated an immediate antitrust exemption in any instance of coordination between a parent and its wholly owned subsidiary. As such, Copperweld has been comprehended to have introduced a conclusively presumed per se exemption from antitrust scrutiny: agreements between parents and wholly owned subsidiaries. The scope of this per se exemption nevertheless remains puzzling as two alternative Copperweld readings could be presented.

One -extensive- way is to read in Copperweld a per se exemption from antitrust law application for all kinds of hybrid corporate affiliation situations. The Copperweld per se exclusion would thus capture alternative affiliations among corporate entities. But how far would this per se exemption go? The Supreme Court specifically did not 'consider under what circumstances, if any, a parent may be liable for conspiring with an affiliated corporation it does not completely own'. ${ }^{52}$ That language did however leave open a potential extension of per se non-applicability to precisely these situations. To what extent could the Copperweld principle of per se intra-enterprise immunity be extended to situations in which a subsidiary was only partially owned by another business? How about franchising agreements, distribution agreements between producer and distributors,...? The scope of Copperweld is

\footnotetext{
${ }^{50}$ Copperweld, note 13 above, 2743-2744.

${ }^{51}$ Copperweld, note 13 above, 2744.

${ }^{52}$ Copperweld, note 13 above, 2739.
} 
potentially limitless and analytical boundaries are difficult to draw. In the words of appellate judge and former Antitrust Division official Michael Boudin, 'once one goes beyond the classical single enterprise, including Copperweld situations, it is difficult to find an easy stopping point or even decide on the proper functional criteria for hybrid cases' ${ }^{53}$

An alternative narrow reading of Copperweld has also remained in swung. That reading aligns with the dissenting opinion voiced by Justice Stevens, but is also reflected throughout the majority opinion in Copperweld. Stevens proposed to analyze all single entity claims exclusively within a rule of reason framework. The parent - wholly owned subsidiary relationship would equally be covered by rule of reason scrutiny. According to Stevens, wholly owned subsidiaries and their parents do not eliminate competition that would otherwise exist; they rather enhance their own ability to compete. ${ }^{54}$ The original purpose of the Sherman Act was to address the use of corporate subsidiaries as devices to eliminate competition. ${ }^{55}$ Establishing a per se rule against intra-enterprise conspiracy leaves 'a significant gap in the enforcement of $\S 1$ with respect to anticompetitive conduct that is entirely unrelated to efficiencies associated with integration'. ${ }^{56}$ Moreover, mere functional integration of subsidiary and parent 'has never been sufficient to establish the existence of an unreasonable restraint of trade' ${ }^{57}$ Actions of affiliated corporations can nevertheless be unrelated to the aim of functional integration and could thus impose restraints on third parties of sufficient magnitude to restrain market-wide competition. ${ }^{58}$ If that were the case, it is appropriate to characterize conduct as a combination or conspiracy in restraint of trade. ${ }^{59}$ Only a full-fledged rule of reason analysis would be able to assess the scope of behaviour of affiliated corporations or businesses.

Based on Justice Stevens' dissent, the narrow approach proposes a rule of reason analysis, except in the specific situation of a parent and a wholly owned subsidiary. In the latter instance, a per se non-application of antitrust law would remain in place. Agreements between otherwise affiliated corporations would be subjected to rule of reason analysis. A footnote in the Copperweld majority opinion seems to confirm that approach. The Court there claimed

\footnotetext{
${ }^{53}$ U.S. Court of Appeals for the First Circuit, Iain Fraser et al. v. Major League Soccer L.L.C. et al. (2002), 284 F.3d 59.

${ }^{54}$ Copperweld, note 13 above, 2745.

${ }^{55}$ Copperweld, note 13 above, 2750.

${ }^{56}$ Copperweld, note 13 above, 2751.

${ }^{57}$ Copperweld, note 13 above, 2752-2753.

${ }^{58}$ Copperweld, note 13 above, 2753.

${ }^{59}$ Copperweld, note 13 above, 2753.
} 
that a single entity tests sets forth various criteria for evaluating whether a given parent and subsidiary are capable of conspiring with each other. Those criteria measure the "separateness" of the subsidiary, rather than to proclaim its unity. They include separate control of day-to-day operations, separate officers, separate headquarters etc. In case of wholly owned subsidiaries however, these separateness criteria do not serve to evaluate the scope of economic unity that is inherent to wholly owned subsidiary constellations. ${ }^{60}$

The narrow reading also invited judges and scholars to devise more nuanced legal tests to assess the scope of single entity claims. Williamson asked whether, on the basis of Copperweld, one could identify other objective criteria for identifying other structures to which the law might yet extend relief ${ }^{61}$. He proposed a nuanced rule of reason framework based on affiliates' control and conduct extracted from the 'common control' and 'unity of interests' requirements voiced in Copperweld. First, courts should determine whether or not the corporations or businesses involved present an economic unity. Economic unity cannot however be limited to a unity of interests, because, even in a fully integrated corporation, conflicting interests continue to engage corporate decision making. ${ }^{62}$ Unity of interests has often been translated into claims of control rights and control mechanisms related to but also potentially different from corporate ownership. ${ }^{63}$ Williamson therefore proposed or at least imagined ownership rights to constitute indications of corporate control. ${ }^{64}$ To the extent that no ownership-based control could be inferred, courts would be invited to assess whether or not the corporations involved constitute actual or potential competitors in the market related to the scrutinized activity. Only in cases where actual or potential competition threats are absent should the courts approve single entity claims. ${ }^{65}$

\subsubsection{Reintroducing rule of reason in American Needle.}

\footnotetext{
${ }^{60}$ Copperweld, note 13 above, 2742, footnote 18.

${ }^{61}$ D. Williamson, note 7 above, 724 .

${ }^{62} \mathrm{D}$. Williamson, note 7 above, 737 and case law references included therein. Other scholars have argued for a framework based on unity of interests and/or unity of conduct in the market. They basically relied on similar criteria, but did not flesh out the nuanced applications of these concepts. See among others G. Feldman, note 10 above, 854-855; J. Stone and J. Wright, note 41 above, 376-379; N. Grow distinguishes unity of interest, common decisionmaking structure and service to increase consumer welfare, see N. Grow, "There is no "I" in "League": Professional Sports Leagues and the Single Entity Defense', Michigan Law Review 105 (2006), 189.

${ }^{63}$ D. Williamson, note 7 above, 736.

${ }^{64} \mathrm{D}$. Williamson, note 7 above, 739-740.

${ }^{65} \mathrm{D}$. Williamson, note 7 above, 741-742.
} 
Both readings remained in swung after Copperweld. A number of federal courts seemed to prefer the narrow reading of Copperweld and applied a rule of reason framework to analyze single entity claims that did not fall within the wholly owned subsidiary situation covered by the Copperweld opinion. ${ }^{66}$ Other courts notably extended Copperweld's per se principle to other hybrid forms of affiliation. ${ }^{67}$ The 2010 American Needle case finally established the scope and existence of per se single entity non-application.

American Needle questioned whether and how antitrust law should regulate 'the peculiar, perhaps incomparable, business entity known as a professional sports league'. ${ }^{68}$ In particular, the Supreme Court was invited to assess whether or not the US National Football League (NFL) constituted a single entity the operations of which could escape antitrust scrutiny. ${ }^{69}$ To the extent that the NFL presented a single entity, decisions taken among its members would not comprise a contract, combination or conspiracy in violation of Section 1.

'The NFL is an unincorporated association that now includes 32 separately owned professional football teams. Each team has its own name, colors, and logo, and owns related intellectual property' ${ }^{70}$ In 1963 , the different teams decided to form a joint National Football League Properties (NFLP) organization to develop license and market their intellectual property and to allow for a redistribution of profits through a NFLP Trust. ${ }^{71}$ NFLP granted nonexclusive licenses to different manufacturers to provide and sell apparel bearing NFL teams' insignias. In 2000 however, the NFL team members allowed NFLP to grant exclusive licenses. NFLP granted an exclusive license to Reebok International Ltd to sell NFL teams'

\footnotetext{
${ }^{66}$ Among many others, see U.S. Court of Appeals for the First Circuit, Iain Fraser et al. v. Major League Soccer L.L.C. et al. (2002), 284 F.3d 47; See C. Sagers, note 34 above, 16-17. For overviews of post-Copperweld case law in relation to sports leagues, see M. Bester, 'The NFL's Quest to be Treated Like General Motors Should Stop at the Supreme Court', Entertainment and Sports Lawyer (2010), 28-29; J. Keyte, 'American Needle Reinvigorates the Single Entity Debate', Antitrust 23 (2009), 49-50; M. McCann, 'American Needle v. NFL: An Opportunity To Reshape Sports Law', Yale Law Journal 119 (2010), 746-747.

${ }^{67}$ Among many others, see U.S. Court of Appeals for the Seventh Circuit, Chicago Professional Sports Ltd. $v$. National Basketball Association (1996), 95 F3.d 593; U.S. Court of Appeals for the Eight Circuit, Pink Supply Corp. v. Hiebert, Inc. (1986), 788 F.2d 1313; U.S. Court of Appeals for the Fourth Circuit, Oksanen v. Page Mem. Hosp. (1991), 945 F.2d 696; U.S. Court of Appeals for the Eleventh Circuit, Day v. Taylor (2005), 400 F.3d 1272. For a more complete overview, see S. Gans, 'Young Lawyers Division Antitrust Committee American Bar Association Section 1 Update: Single Entity Defense', presentation 23 February 2010, accessible at apps.americanbar.org/antitrust/at.../at-s1/.../SingleEntityDefense-Gans.PPT. See also U.S. Court of Appeals for the Seventh Circuit, American Needle, Inc. v. National Football League (2008), F.3d 736.

${ }^{68}$ M. McCann, note 66 above, 728.

${ }^{69}$ American Needle, note 14 above, 2206. The U.S. Supreme Court decided the case unanimously. No concurring or dissenting opinions were filed.

${ }^{70}$ American Needle, note 14 above, 2207.

${ }^{71}$ See M. McCann, note 66 above, 731.
} 
logoed headwear. As a consequence, it did not renew the nonexclusive license of American Needle, another company engaged in the headwear business. ${ }^{72}$

American Needle responded to its termination of license by filing a claim alleging that the agreements between the NFL, its teams, NFLP and Reebok violated section 1 of the Sherman Act. $^{73}$ The NFL and its constituent teams claimed that they were unable to conspire, because they comprise a single economic enterprise for the purposes of their licensing business. Both the federal District Court and the Court of Appeals for the Seventh Circuit upheld the NFL's single entity claim. ${ }^{74}$ With regard to the licensing of intellectual property rights, the NFL teams can function only as one source of economic power when collectively producing NFL football. ${ }^{75}$ More specifically, the Seventh Circuit argued that in some contexts, a league seems more aptly described as a single entity immune from antitrust scrutiny, while in others a league appears to be a joint venture between independently owned teams that is subject to review under $\S 11^{76}$ The context of this dispute warranted recognition of the NFL's single entity status.

\footnotetext{
${ }^{72}$ American Needle, note 14 above, 2207.

${ }^{73}$ American Needle, note 14 above, 2207.

${ }^{74}$ U.S. Court of Appeals for the Seventh Circuit, American Needle, Inc. v. National Football League (2008), F.3d 741. The Seventh Circuit relied on its own precedent in Bulls II, a case in which Judge Easterbrook had argued that a sports league could potentially be regarded as a single entity for particular league purposes. See U.S. Court of Appeals for the Seventh Circuit, Chicago Professional Sports Ltd. v. National Basketball Association (1996), 95 F3.d 593. In so doing, the Seventh Circuit confirmed the U.S. District Court for the Northern District of Illinois, granting single entity status to the NFL for intellectual property purposes, see U.S. District Court for the Northern District of Illinois, American Needle, Inc. v. New Orleans La. Saints (2007), 496 FSupp. 2d 943. For a critique on that approach, see M. Edelman, 'Why the "Single Entity" Defense can never apply to NFL Clubs: A Primer on Property-Rights Theory in Professional Sports', Fordham Intellectual Property, Media and Entertainment Law Journal 18 (2008), 891-927. See also N. Grow, 'A Proper Analysis of the National Football League Under Section One of the Sherman Act', Texas Review of Entertainment \& Sports Law 9 (2008), 281-305; J. McKeown, 'Antitrust Developments in Professional Sports: To the Single Entity and Beyond', Marquette Sports Law Review 19 (2009), 363 -393; P. R. Morrison, 'Shutting Down the Offense: Why the Supreme Court Should Designate the NFL a Single Entity for Antitrust Purposes', Journal of Business, Entrepreneurship and the Law 3 (2009), 97-132; S. Semeraro, 'Is the National Football League a "Single Entity" Incapable of Conspiring under the Sherman Act?: The Supreme Court Will Decide', Thomas Jefferson Law Review 32 (2009), 1 -19; D. Taylor, 'Splitting the Uprights: How the Seventh Circuit's American Needle Holding Create a Circuit Split and Exempted the NFL From Antitrust Scrutiny, and Why the Supreme Court Should Overturn the Seventh Circuit', DePaul Journal of Sports Law \& Contemporary Problems 6 (2010), 143 171; C.J. Avgiris, 'Huddle Up: Surveying the Playing Field on the Single Entity Status of the National Football League in Anticipation of American Needle v. NFL', Villanova Sports and Entertainment Law Journal 17 (2010), 529 -571; M. S. LeBlanc, 'American Needle, Inc. v. NFL: Professional Sports Leagues and "SingleEntity" Antitrust Exemption', Duke Journal of Constitutional Law and Public Policy Sidebar 5 (2010), 148-160.

${ }^{75}$ U.S. Court of Appeals for the Seventh Circuit, American Needle, Inc. v. National Football League (2008), F.3d 743

${ }^{76}$ U.S. Court of Appeals for the Seventh Circuit, American Needle, Inc. v. National Football League (2008), F.3d 741. See also American Needle, note 14 above, 2207.
} 
In a unanimous opinion authored by Justice Stevens - the dissenting Justice in Copperweld - , the U.S. Supreme Court overturned the Seventh Circuit and at the very least confirmed a preference for a narrow reading of Copperweld. ${ }^{77}$

Justice Stevens held that "we have eschewed [...] formalistic distinctions in favor of a functional consideration of how the parties involved in the alleged anticompetitive conduct actually operate' ${ }^{78}$ A functional approach inquires whether the alleged contract is actually concerted action, i.e. whether or not separate economic actors pursuing separate economic interests have been involved. ${ }^{79}$ That is only the case to the extent that the agreement deprives the marketplace of independent centers of decisionmaking, of a diversity of entrepreneurial interests and of actual or potential competition. ${ }^{80} \mathrm{~A}$ functional approach has allowed the Supreme Court to find section 1 violations in cases where a legally single entity was actually controlled by a group of competitors, serving as a vehicle for ongoing concerted activity. ${ }^{81} \mathrm{It}$ has equally provided multiple corporate legal entities with assertions that they have a complete 'unity of interests', and therefore act as one economic single unity. ${ }^{82}$ An entity can thus comprise different entities for the purposes of incorporation or formal title, even though it reflects a single center of decision-making and controls a single aggregation of economic power. $^{83}$

In the particular context of American Needle, the NFL teams do not appear to act as one single entity. 'Each of the teams is a substantial, independently owned, and independently managed business. Their general corporate actions are guided or determined by separate

\footnotetext{
${ }^{77}$ For a brief analysis, see H. Hovenkamp, 'American Needle: the Sherman Act, Conspiracy, and Exclusion', The Competition Policy International Antitrust Journal (2010), to be consulted at www.competitionpolicyinternational.com, 8p. Comments on American Needle have mainly focused on future antitrust scrutiny for sports leagues and on the future of the single entity defense in that regard. See S. Adkins, note 19 above, 21-38 and M. McCann, note 66 above, 726-781. In addition to these articles, see R. S. Jeffrey, 'Beyond the Hype: The Legal and Practical Consequences of American Needle', Florida Coastal Law Review 11 (2010), 667 -686; M. McCann, 'The NBA and the Single Entity Defense: A Better Case?', Harvard Journal of Sports and Entertainment Law 1 (2010), 39-61; M. Jakobzse, "Kicking "Single-Entity" to the Sidelines: Reevaluating the Competitive Reality of Major League Soccer after American Needle and the 2010 Collective Bargaining Agreement', Northern Illinois University Law Review 31 (2010), 131-174; N. Grow, 'American Needle and the Future of the Single Entity Defense under Section One of the Sherman Act', forthcoming American Journal of Business Law 2011, electronic copy available at http://papers.ssrn.com/sol3/papers.cfm?abstract_id=1702644.

${ }_{78}$ American Needle, note 14 above, 2209.

${ }^{79}$ As such, the concept of single entity is confusing, for it seems to denote a single corporation or a single name. See American Needle, note 14 above, 2211-2212.

${ }^{80}$ American Needle, note 14 above, 2212.

${ }^{81}$ American Needle, note 14 above, 2209.

${ }^{82}$ American Needle, note 14 above, 2210.

${ }^{83}$ American Needle, note 14 above, 2211.
} 
corporate consciousnesses and their objectives are not common' ${ }^{84}$ The teams are constantly competing, 'not only on the playing field, but to attract fans, for gate receipts and for contracts with managerial and playing personnel' and in the market for intellectual property. ${ }^{85}$ 'Decisions by NFL teams to license their separately owned trademarks collectively and to only one vendor are decisions that deprive the marketplace of independent centres of decision-making, ${ }^{86}$

The teams argued that the creation of a single legal person, NFLP, justified its single entity defense. That argument reflects the intuitively appealing claim that 'a defining characteristic of a single entity is that control is concentrated in the hands of a single party' ${ }^{87}$ NFLP, according to the defendants in American Needle, presented single party control and should therefore be granted per se relief from antitrust scrutiny. The Supreme Court replied that giving an ongoing Section 1 violation a new name or label does not evade antitrust scrutiny. ${ }^{88}$ Moreover, even though the Court generally treats 'agreements within a single firm as independent action on the presumption that the components of the firm will act to maximize the firm's profits', the presumption does not hold in rare cases 'when the parties to the agreement act on interests separate from those of the firm itself and the intra-firm agreements may simply be a formalistic shell for ongoing concerted action' ${ }^{89}$ The collective licensing of intellectual property through NFLP could potentially represent such a rare case. To discover those cases, a rule of reason analysis is preferable over an extension of per se rules. ${ }^{90}$

The Supreme Court thus held that sports leagues' conduct related to intellectual property licensing is not categorically (or per se) beyond section 1's coverage. ${ }^{91}$ American Needle's single entity claim therefore needed to be reassessed under a rule of reason analysis. ${ }^{92}$ The Court nevertheless remains cryptic, adding that depending upon the activity in question, the rule of reason can at times be applied in its quick look fashion, without specifically

\footnotetext{
${ }^{84}$ American Needle, note 14 above, 2212.

${ }^{85}$ American Needle, note 14 above, 2212.

${ }^{86}$ American Needle, note 14 above, 2212-2213.

${ }^{87}$ D. Williamson, note 7 above, 726.

${ }^{88}$ American Needle, note 14 above, 2213.

${ }^{89}$ American Needle, note 14 above, 2215.

${ }^{90}$ American Needle, note 14 above, 2216.

${ }^{91}$ American Needle, note 14 above, 2215.

${ }^{92}$ American Needle, note 14 above, 2216.
} 
explaining when and how. ${ }^{93}$ The U.S. Supreme Court remanded the case to the District Court for further proceedings. ${ }^{94}$

\subsection{Single entity test after American Needle}

American Needle clearly restructures and clarifies the single entity defense into a broader rule of reason framework. ${ }^{95}$ The confines of the rule of reason single entity test nevertheless remain unclear and it will be in the hands of lower courts to reinterpret the status of single entity defenses as a matter of U.S. antitrust law. In this section, we briefly extract the conditions that have guided the Supreme Court in framing its American Needle single entity defense. These conditions constitute the basis for a full-fledged U.S. antitrust law single entity test, focusing on the absence of independent centers of decisionmaking, the absence of concurring entrepreneurial interests and the lack of actual or potential competition among constituent entities. ${ }^{96}$

American Needle did not explicitly overrule Copperweld, but re-interpreted its meaning to propose a rule of reason test rather than a per se approach to affiliated corporations. In the words of one group of commentators, 'before American Needle, lower courts agreed that complete common ownership was a sufficient condition for single-entity status but not, perhaps a necessary one. Following American Needle, complete common ownership now appears to be a necessary condition for single-entity status, but not a sufficient one'. ${ }^{97}$ Even though the underlying rationale of that claim is correct, we read American Needle's single entity test in a more nuanced way. Copperweld's per se approach does no longer present the dominant analytical framework to address any single entity defense in U.S. antitrust law. American Needle seemingly presents an open-ended rule of reason framework, allowing wholly owned subsidiaries to be excluded from section 1 scrutiny under a (quick look) rule of reason analysis. ${ }^{98}$ At the same time, the opinion does not require common ownership to be necessary to establish single entity status. It rather allows a more nuanced single entity test to be developed, capturing both wholly owned subsidiaries and hybrid affiliations among corporate entities.

\footnotetext{
${ }^{93}$ American Needle, note 14 above, 2217.

${ }^{94}$ American Needle, note 14 above, 2217.

95 J. Stone and J. Wright, note 41 above, 394.

${ }^{96}$ Distinguished in American Needle, note 14 above, 2212.

${ }^{97}$ J. Stone and J. Wright, note 41 above, 395.

${ }^{98}$ American Needle, note 14 above, 2216.
} 
The American Needle opinion does not explicitly proclaim a single 'single entity' testing framework. The opinion rather presents the conditions for a judicially refined single entity analysis framework. ${ }^{99}$ American Needle distinguishes three conditions: control (absence of independent decisionmaking centers), interests (absence of concurring entrepreneurial interests) and 'competitive links' (lack of actual or potential competition). ${ }^{100}$ The interactions among these three conditions can be captured by the establishment of presumptions and rule of reason shortcuts ${ }^{101}$ that can be extracted from earlier case law, American Needle and scholarly proposals. That would lead to the following three step single entity test, combining Williamson's two-step test and American Needle analysis.

${ }^{99}$ A stricter single entity test, based on similar concerns, has been adopted in relation to U.S. government contracted entities and closely related corporations. To the extent the latter present a close connection the former, specific federal labour law protections also apply to these entities, because they constitute a single entity. The test has been described as follows: A separate business or organization without Government contracts may be covered under the laws enforced by OFCCP based on an integrated relationship or "single entity" status with a Government contractor. OFCCP uses a five-factor test for determining whether such a relationship exists. The test requires $O F C C P$ to consider whether:

1. the entities have common ownership;

2. the entities have common directors and/or officers;

3. one entity has de facto day-to-day control over the other through policies, management or supervision of the entity's operations;

4. the personnel policies of the entities emanate from a common or centralized source; and

5. the operations of the entities are dependent on each other, e.g., services are provided principally for the benefit of one entity by another and/or both entities share management, offices, or other services.

The test focuses primarily on whether the ownership, management, and operations of the separate entities are, in fact, sufficiently interrelated to warrant treating them as an integrated enterprise or a single entity. A business or organization need not meet all five factors to be considered a single entity with a covered Federal contractor. However, there is growing recognition that centralized control over labor relations and personnel functions is the most important factor. By way of example, say that two entities are under common ownership, with a common board of directors, and have a central corporate office that determines and issues personnel policy for both entities, and generally manages most personnel-related issues for both entities. At the same time, the operations of the two entities are not particularly dependent on each other. Despite the fact that one of the factors did not apply, the four factors that did outweigh the one that did not, so that the two entities being analyzed will most likely be considered a single entity. See http://www.dol.gov/elaws/esa/ofccp/single_entity_test.asp.As the example highlights, the U.S. legislator did allow for a more flexible application of single entity claims as well. Whereas the abovementioned test emphasizes common ownership, the Supreme Court's opinion did not necessarily exclude other forms of ownership.

${ }^{100}$ American Needle, note 14 above, 2212.

101 The application of any rule of reason shortcuts through a truncated or quick look rule of reason is apparent from the American Needle opinion, see American Needle, note 14 above, 2216-2217, depending on the concerted activity in question. As will be shown in this chapter, we build on the Court's invitation to include rule of reason shortcuts in a testing framework. More specifically, we take the reference to truncated rule of reason as a translation of per se exemptions into truncated rule of reason exemptions, as our analysis will demonstrate. 
First, considerations of control implicitly dominate current scholarly and judicial argumentation. ${ }^{102}$ The concept of control is elusive. It should be understood as legal regimes allowing particular corporate entities or individuals to influence decision making processes in other corporate entities. ${ }^{103}$ Control thus operationalizes part of the unity of interests claims developed in Copperweld. The presence of control rights themselves allows courts to evaluate the extent of separateness among affiliated or non-affiliated actors. Control embraces a variety of legal regimes of affirmative or negative rights enabling cooperative or hierarchical relationships among different corporate entities to be structured and maintained. ${ }^{104}$ Affirmative rights establish rights to redeploy assets or impose initiatives, including the right to delegate functions or to exit a governance structure without obtaining approval. These rights are often - but do not have to be - connected to company ownership. ${ }^{105}$ Negative control rights on the other hand are rights to block other parties initiatives, through approval or veto procedures. Again, these rights could be related to ownership, and often are, but do not necessarily have to be held solely by a majority shareholder. ${ }^{106}$ The presence of strong affirmative and negative control rights could reflect a prima facie unity of purpose or interests.

The extent to which control rights establish presumptions of single entity is unclear at best. The types or kinds of affirmative or negative rights that are determinate in establishing single entity status are difficult to detect in the abstract and without full-fledged rule of reason analysis. It therefore remains to be seen how much weight will be attached to particular control rights.

Control rights could - but should not - be related to ownership rights. A first step in analyzing control could thus be the reflection of ownership structures. In a Copperweld situation (wholly owned subsidiary, or unincorporated divisions or entity-employee relationships), ownership structures typically include both affirmative and negative control rights. It could therefore be assumed that full ownership implies control and that control allow for attribution

\footnotetext{
${ }^{102}$ Even though J. Stone and J. Wright, note 41 above, 379, argue that interests outweigh control in single entity analysis, their focus on Copperweld presumes elements of control to be present in the background; D. Williamson, note 7 above,734. Control aspects did determine Copperweld's outcome and appeared in the language of 'separate decisionmaking centers' in American Needle.

${ }^{103}$ Control is often associated with the theory of the firm in economics. For more references in that regard, see W. Wils, note 1 above, 102-104; J. Stone and J. Wright, note 41 above, 379-381.

${ }^{104}$ D. Williamson, note 7 above, 738-739.

${ }^{105}$ D. Williamson, note 7 above, 736.

${ }^{106}$ D. Williamson, note 7 above, 738.
} 
of single entity status in those instances. Whereas Copperweld seemed to establish a conclusive, non-rebuttable per se presumption, American Needle turned this presumption semi-conclusive. ${ }^{107}$ Copperweld situations still present a strong case against antitrust scrutiny, but it would not seem improbable that in particular cases, evidence to the contrary could be adduced in a rule of reason framework. ${ }^{108}$ Because of the overwhelming presumption of control in Copperweld situations, a quick look or truncated rule of reason analysis would seem most appropriate in this stage of the single entity test. ${ }^{109}$

Ownership and control are not always inherently related. ${ }^{110}$ Ownership merely constitutes a proxy in a control rights analysis. Applying a truncated rule of reason analysis, courts could also establish the extent of control rights in non-Copperweld situations. These situations include all sorts of hybrid affiliations such as particular joint ventures in sports leagues. In those situations, the courts would have to look for alternative affirmative or negative control rights to establish single entity status. As such, the Supreme Court (and lower courts) would be invited to establish scenarios in which particular affirmative or negative rights are more apt to presume control. According to some courts and scholars, affirmative approval rights and are good proxies of control, presenting sufficient evidence to establish the absence of separate decisionmaking centers. ${ }^{111}$ A quick look investigation into these rights serves as an analytical barrier for a more full-fledged rule of reason analysis. To the extent that no significant elements of affirmative or negative control can be detected, the courts should proceed with a more careful rule of reason analysis to establish control. In the event of insignificant or limited control rights, the single entity plea should immediately be rejected.

Second, requirements of diversity of entrepreneurial interests imposes additional elements to the rule of reason analysis American Needle promotes. Once a sufficient or significant depending on the Supreme Court's further elaborations on this matter - standard of control has been established, most cases do not allow for the determination of single entity status in and

\footnotetext{
${ }^{107}$ J. Stone and J. Wright, note 41 above, 395.

108 That seems to align with the approach taken by the U.S. Supreme Court outside the field of antitrust law, e.g. U.S. Supreme Court, United States v. BestFoods, 118 S.Ct. 1876. Burnley extracts from this case that a parent company has to be directly involved or has to appear as a sham, see R. Burnley, note 3 above, 597-598. BestFoods nevertheless presents a case outside the realm of antitrust law and does not appear to reflect a taste for an antitrust single entity test.

109 See Justice Stevens' approach in American Needle on this subject. American Needle, note 14 above, combined reading of 2212 and 2217.

${ }^{110}$ See on that notion the well-known treatise by A. Berle and G. Means, The Modern Corporation and Private Property (New York, Harcourt, 1968 Revised edition), 380 p.; D. Williamson, note 7 above, 737.

${ }^{111}$ See American Needle, note 14 above, 2212.
} 
of itself. The notion of 'entrepreneurial interests' requires courts to analyze present control rights within a broader corporate operational framework. ${ }^{112}$ The entrepreneurial interest analysis does not specifically consider competitive interests or the situation in which both entities actually constitute competitors in a particular market. Rather, entrepreneurial interests aim to define whether and to what extent the reasons for different entities establishing and accepting control rights concur or differ. Are these control rights mutual or do they represent a subordination of one entity to another? In the former case, the interests of both entities to establish control rights could be related to diverse entrepreneurs aiming to collaborate despite divergences in entrepreneurial interests. In the latter, control rights would seem to imply the creation of a subordinated entity to facilitate realization of concurring interests. Even in that case however, the inquiry should focus on what entities hold control rights. To the extent that two different entities entertain similar control rights, a presumption of concurring entrepreneurial interests might not hold as both entities might actually engage in illicit cartelizing behaviour. From that perspective, the creation of joint ventures might pose particular problems from a single entity vantage point. ${ }^{113}$

The diversity of entrepreneurial interests stage thus bridges control rights and conduct investigations and allows for another truncated analysis of what would otherwise imply a fullfledged rule of reason analysis. Whereas Copperweld situations again establish a rebuttable presumption of concurring entrepreneurial interests, other situations could equally be captured by a similar presumption. The unilateral establishment of a particular balanced combination of affirmative and negative control rights could also presume a concurrence of entrepreneurial interests. The courts will nevertheless have to strike that balance more clearly. In that respect, the nature and establishment conditions of control rights present a second truncated or quick look phase towards single entity claims. To the extent that a presumption of concurring entrepreneurial interests can be established through a quick look analysis, a presumption of single entity would seem to apply.

\footnotetext{
112 Questions have been raised whether this should be the (antitrust) judge's role. At the very least, the operationalization of this test is problematic, see G. Feldman, note 10 above, 873-874. The Supreme Court in American Needle nevertheless continued to refer to a diversity of interests criterion as a part of single entity rule of reason analysis. Preferring control over interests, J. Keyte, note 66 above, 51

${ }^{113}$ On joint ventures and single entity analysis, see U.S. Supreme Court, Texaco Inc. v. Dagher (2006), 126 S. Ct. 1276; the Supreme Court held that selling separately branded gasoline at the same price through one joint venture did not amount to price fixing. On the implications of American Needle on that case, see C. Sagers, note 10 above, 8; E. Grush and C. Korenblit, note 29 above, 56-58; J. McKeown, note 74 above, 372.
} 
A third condition can be related to the absence of actual or potential competition or 'complementarity' ${ }^{114}$ among parts of a presumed single entity. Absence of actual or potential competition functions as an additional condition, allowing even fully controlled and incentivised businesses to be considered more than just single entities in cases of particular market conduct. It assesses whether or not the entities present themselves as actual or potential competitors in the market. Questions remain whether or not actual or potential competitors should be considered in light of a metaphysical market or in light of the market to which antitrust infringements could be related. In the former case, controlling rights and interests could more easily support the conclusion that entities are competitors in "the" market. In the latter case, which is the preferable choice, a full rule of reason analysis, including determining the relevant market and market shares of entities would be required to determine the activities of controlling (and controlled) entities in a particular market segment, at least to the extent that they constitute actual competitors. ${ }^{115}$ If no actual competition seems present, the potentiality of these entities competing in a particular market segment should be predicted. American Needle seems to rely on that approach, assessing the potential competitive relationships among NFL teams in the intellectual property markets. ${ }^{116}$ The potential competition test assesses whether or not potential single entity parties provide complementary inputs in the productive process or whether they basically foreclose new market developments. ${ }^{117}$ In Copperweld situations, the overwhelming controlling relationship would seem to make potential competition among parent and subsidiary illusory, even if both engage in different market activities. To that extent, significant market evidence would have to be adduced to condemn the Copperweld relationship as a cartel. Based on the Supreme Court's reading, that situation is not likely to occur, but at the very least remains a theoretical possibility. The abovementioned hypothetical situation of presumed diverse entrepreneurial interests would equally establish a presumption of potential competition in the relevant market, thus allowing a quick look analysis to market structure in order to defeat a single entity claim. In both instances, it is clear that this third stage mainly serves as an additional phase in which to rebut or confirm presumptions related to earlier stages. In cases where a reasonable element of control and concurring entrepreneurial interest appears, this phase's

\footnotetext{
${ }^{114}$ D. Williamson, note 7 above, 742 refers to the notion of complementarity. We prefer to use the broader and more familiar notion of 'absence of actual or potential competition'.

115 American Needle, note 14 above, combined reading of 2213 and 2216. D. Williamson, note 7 above, 742.

${ }^{116}$ Even though these competitive relationships in the market not always clear, specifically in relation to labor regulations, N. Grow, note 74 above, 287-288.

${ }^{117}$ D. Williamson, note 7 above, 742 .
} 
full-fledged rule of reason could provide more analytical certainty about a single entity's (non-)existence.

Table 1 distinguishes four categories of affiliation through which the rule of reason analysis could operate differently:

Table 1: U.S. Single Entity testing framework

\begin{tabular}{|c|c|c|c|c|}
\hline Single entity test & $\begin{array}{l}\text { Copperweld } \\
\text { situation }\end{array}$ & $\begin{array}{l}\text { Hybrid situation } \\
1\end{array}$ & $\begin{array}{l}\text { Hybrid situation } \\
2\end{array}$ & $\begin{array}{l}\text { Hybrid situation } \\
3\end{array}$ \\
\hline Control & $\begin{array}{l}\text { Quick Look: } \\
\text { presumption of } \\
\text { control }\end{array}$ & $\begin{array}{l}\text { Quick Look: } \\
\text { presumption of } \\
\text { control if balance } \\
\text { of affirmative } \\
\text { and negative } \\
\text { rights }\end{array}$ & $\begin{array}{l}\text { Quick Look: } \\
\text { presumption of } \\
\text { control if balance } \\
\text { of affirmative } \\
\text { and negative } \\
\text { rights }\end{array}$ & $\begin{array}{l}\text { Full rule of } \\
\text { reason if unable } \\
\text { to prima facie } \\
\text { establish } \\
\text { presence of } \\
\text { control rights }\end{array}$ \\
\hline $\begin{array}{l}\text { Absence of } \\
\text { Diverse } \\
\text { Entrepreneurial } \\
\text { Interests }\end{array}$ & $\begin{array}{l}\text { Quick look: } \\
\text { rebuttable } \\
\text { presumption of } \\
\text { unity of interests }\end{array}$ & $\begin{array}{l}\text { Quick Look: } \\
\text { presumed } \\
\text { unilateral } \\
\text { operations of } \\
\text { control rights }\end{array}$ & $\begin{array}{l}\text { Mutual operation } \\
\text { of control rights: } \\
\text { rule of reason } \\
\text { analysis }\end{array}$ & $\begin{array}{l}\text { Included in full } \\
\text { rule of reason } \\
\text { analysis }\end{array}$ \\
\hline $\begin{array}{l}\text { Lack of Actual or } \\
\text { Potential } \\
\text { Competition }\end{array}$ & $\begin{array}{l}\text { Presumed on the } \\
\text { basis of } \\
\text { foregoing, } \\
\text { rebuttable on } \\
\text { potential } \\
\text { competition } \\
\text { grounds }\end{array}$ & $\begin{array}{l}\text { Presumed if } \\
\text { complementary } \\
\text { market activities }\end{array}$ & $\begin{array}{l}\text { Included in full } \\
\text { rule of reason } \\
\text { analysis }\end{array}$ & $\begin{array}{l}\text { Included in full } \\
\text { rule of reason } \\
\text { analysis }\end{array}$ \\
\hline
\end{tabular}

The operational conditions thus initially present themselves as cumulative conditions, each of them in itself insufficient to establish single entity status. Only to the extent that the Copperweld rationale applies, a now rebuttable presumption of single entity can be 
maintained throughout. Intra-corporation agreements between unincorporated divisions, between employees and between wholly-owned subsidiaries, or the latter and parents could indeed gain single entity status with the twinkling of an eye. ${ }^{118}$ In other instances, courts will have to carve out whether and to what extent presumptions of control, incentives or competitive links merit truncated or full-fledged rule of reason to either rebut or confirm what has been presumed, as exemplified in the abovementioned algorithm. Rather than settling debates on single entity, American Needle invigorated a new era of more intense judicial operationalization of a rule of reason single entity test.

\section{Single entity claims in EU competition law}

This part discusses single entity claims in EU competition law. The concept of single entity is structured within the undertaking concept in EU law (section 1). The notion of undertaking has been applied to limit the scope of competition law enforcement (section 2), but more recently, focus has shifted towards extending the scope of imputation of fines (section 3). Both approaches rely on similar concepts and reflect a the nascence of an EU single entity test based on control and conduct conceptions similar to those in U.S. antitrust law (section 4).

3.1.The entity component of undertakings and the application and enforcement of EU competition law

Single entity analysis in EU law is enshrined a broader 'undertaking' concept. ${ }^{119}$ The notion of undertaking is pivotal for the scope of application of EU competition law. As is wellknown, Article 101 TFEU prohibits restrictive agreements between undertakings, whereas Article 102 prohibits undertakings to abuse a dominant market position. Agreements or coordinated action among components of a single undertaking fall outside the scope of the Article 101 prohibition. ${ }^{120}$ They can only be captured by the Article 102 prohibition if these single undertaking components engage in abusive market behaviour. ${ }^{121}$

\footnotetext{
118 U.S. Supreme Court, National Collegiate Athletic Assn. v. Board of Regents of Univ. of Okla.(1984), 104 S.Ct. 2948.

${ }^{119}$ European Court of Justice (hereafter referred to as ECJ), Joined cases 56/64 and 58/64, Établissements Consten S.à.R.L. and Grundig-Verkaufs-GmbH v Commission of the European Economic Community [1966] ECR 299, 340; ECJ, case 30/87 Corinne Bodson v SA Pompes funèbres des régions libérées [1988] ECR 2479, para. 19 (hereafter referred to as Bodson); P. Nihoul, 'Do workers constitute undertakings for the purpose of the competition rules?', E.L.Rev. 2000, 25 (4), (408) 412; L. Ritter and W. Braun, European competition law: a practitioner's guide, (The Hague, Kluwer law international, 2004, $3^{\text {rd }}$ ed.), 46.

${ }^{120}$ This rationale has also been expressed by the European Court of Justice in its case law e.g. case 48/69, Imperial Chemical Industries Ltd. v Commission of the European Communities [1972] ECR 619, para. 134; case 15/74, Centrafarm BV et Adriaan de Peijper v Sterling Drug Inc. [1974] ECR 1147, para. 41; case 170/83, Hydrotherm Gerätebau GmbH v Compact del Dott. Ing. Mario Andreoli \& C. Sas. [1984] ECR I-3969, para. 11; case T-11/89, Shell International Chemical Company Ltd v Commission of the European Communities [1992]
} 
The presence and scope of an undertaking depends on judicially established conditions and limits. From the 1991 Höfner judgment onwards ${ }^{122}$, the European Court of Justice (ECJ) consistently set forth a single definition of undertaking: 'the concept of an undertaking encompasses every entity engaged in an economic activity, regardless of the legal status of the entity and the way in which it is financed'. ${ }^{123}$ This definition comprises two components: entity and economic activity. ${ }^{124}$ The second component mainly determines the extent to which particular activities can be considered 'economic'. The case law on this component assesses whether social security providers or public enterprises engage in economic activities. ${ }^{125}$ That question is not directly relevant for our analysis of the entity component and will not be discussed here.

The basic elements of the (single) entity component have been interpreted quite consistently over time. ${ }^{126}$ In the Shell-case ${ }^{127}$ the General Court stated that a single entity is an 'economic unit which consist of an unitary organization of personal, tangible and intangible elements which pursues a specific economic aim on a long-term basis and can contribute to the

ECR II-757, para. 311 (hereafter called Shell); Joined cases C-2/01 P and C-3/01 P BAI and Commission v Bayer ,[2004] ECR I-23, para. 97.

${ }^{121}$ As such, the concept of undertaking imposes a barrier comparable to the one imposed by the Sherman Act. See on the undertaking concept and Article 102 abuses, see A. Jones and B. Sufrin, EU competition law: text, cases, and materials (Oxford, Oxford University Press, 2011, 4rth ed.), 259.

${ }^{122}$ Case C-41/90 Klaus Höfner and Fritz Elser v Macrotron GmbH. [1991] ECR I-1979 (hereafter referred to as Höfner).

${ }^{123}$ Höfner, note 122 above, para. 21.

${ }^{124}$ Case C-55/96, Job Centre coop. Arl. [1997] ECR I-7119, para 21; Case C-35/96, Commission of the European Communities v Italian Republic [1998] ECR I-3851, para. 36; Case T-9/99, HFB Holding für Fernwärmetechnik Beteiligungsgesellschaft $\mathrm{mbH} \& \mathrm{Co} . \mathrm{KG}$ and Others $v$ Commission of the European Communities [2002] ECR II-1487, para. 66; Case C-309/99, J. C. J. Wouters, J. W. Savelbergh and Price Waterhouse Belastingadviseurs BV v Algemene Raad van de Nederlandse Orde van Advocaten, intervener: Raad van de Balies van de Europese Gemeenschap [2002] ECR I-1577, para. 46; Joined Cases C-264/01, C-306/01, C-354/01 and C-355/01, AOK Bundesverband and Others v Ichthyol-Gesellschaft Cordes, Hermani \& Co. and Others [2004] ECR I-2493, para. 46; Joined Cases C-189/02 P, C-202/02 P, C-205/02 P to C-208/02 P and C-213/02 P, Dansk Rorindustri and Others $v$ Commission of the European Communities [2005] ECR I-5425, para. 112; The definition had already been used by the Commission in an earlier case: Commission Decision 86/398/EEC relating to a proceeding under Article 85 of the EEC Treaty (IV/31.149 - Polypropylene) [1986], para. 99.

${ }^{125}$ See on that issue, among many others, N. Dunne, 'Knowing when to see it: State Activities, Economic Activities and the Concept of Undertaking', Columbia Journal of European Law 16 (2009-2010), 427-463; M. Szydlo, 'Leeway of Member States in Shaping the Notion of an 'Undertaking' in Competition Law', W.Comp. 33 (2010), 549-568.

${ }^{126}$ In the following, we mainly focus on Court decisions rather than on Commission decisions. Although the European Commission is the first antitrust enforcement authority to apply and develop a single entity test, the latter has to be sanctioned by the Courts. These judicial tests therefore possess (at least in theory) more finality as they guide the Commission in its enforcement endeavors.

127 Case T-11/89, Shell International Chemical Company Ltd v Commission of the European Communities [1992] ECR II-757 (hereafter referred to as Shell). 
commission of an infringement of the kind referred to in that provision' ${ }^{128}$ Earlier ECJ case law stated that an entity could consist of 'several persons, natural or legal'. ${ }^{129}$ In particular, multiple legal persons could be considered a single entity if business or personal links exist between those legal persons. The notion of business links refers to a parent company effectively influencing commercial policy, personal links relate to the sharing of directors or executives among different legal persons. ${ }^{130}$ Not unlike U.S. antitrust law, the single entity concept is thus approached from a functional perspective. Legal personhood does not play a determining role in establishing the limits of the undertaking concept.

The entity concept thus determines the scope of application of EU competition law. To the extent that a particular business structure does not fit the entity definition, EU competition prohibitions will not apply to that structure's behaviour. Simultaneously, the single entity notion also determines the scope of the structure 'to which a certain behaviour is attributable'. ${ }^{131}$ The latter function allows competition authorities to develop single entity claims in order to impose fines on groups of corporate entities. Single entity claims in that respect enhance competition law prosecution. According to Regulation 1/2003, the fines imposed on undertakings or associations of undertakings when infringements of the articles 101 and 102 of the Treaty are committed intentionally or negligently, shall not exceed $10 \%$ of the total turnover in the preceding business year of each undertaking and association of undertakings participating in the infringement. ${ }^{132}$ Group members can thus be held jointly and severally liable for competition law infringements. ${ }^{133}$ A more extensive entity conception that integrates different legal entities into a single economic entity allows for higher fines to be calculated on the turnover of every component of that single entity.

\footnotetext{
${ }^{128}$ Shell, note 127 above, para. 311; This definition had already been set out by the ECJ in former cases e.g. Joined cases 17/61 and 20/61, Klöckner-Werke AG and Hoesch AG v High Authority of the European Coal and Steel Community, [1962] ECR. 325, 341 (Hereafter referred to as Klöckner).

${ }^{129}$ Case 170/83, Hydrotherm Gerätebau GmbH v Compact del Dott. Ing. Mario Andreoli \& C. Sas. [1984] ECR 2999, para. 11 with this the ECJ overruled its earlier case law in which it stated that «An undertaking is constituted by a single organization of personal, tangible and intangible elements, attached to an autonomous legal entity and pursuing a given long term economic aim. According to this concept the creation of every legal entity in the field of economic organization involves the establishment of a separate undertaking» (see Klöckner, note 128 above, 341 )

${ }^{130}$ A. Montesa and A. Givaja, note 3 above, 569.

131 Advocate General Jacobs in his Opinion to case C-67/96 Albany International BV $v$ Stichting Bedrijfspensioenfonds Textielindustrie [1999], para 206.

${ }^{132}$ Article 23 (2) of the Council Regulation 1/2003 of 16 December 2002 on the implementation of the rules on competition laid down in Articles 81 and 82 of the Treaty, O.J. L 1, 1.

${ }^{133}$ L. La Rocca, note 5 above, 71.
} 


\subsection{Single entity defenses in EU competition law}

The single entity concept has long provided groups of corporate legal persons with an escape from EU competition law. In 1971, the ECJ held that one undertaking could comprise several corporations which can be organized in a simple parent company and subsidiary scheme or in even more complex schemes with several levels of subsidiaries. ${ }^{134}$ When dealing with a group of undertakings, the constituent factor one should bear in mind is not whether those undertakings have a separate legal personality, but whether or not they act together on the market as a single unit. ${ }^{135}$ Single unit market conduct implies that a subsidiary or affiliate has no real freedom to determine its course of action on the market. ${ }^{136}$ The assessment of single economic unit status crucially depends on control and conduct factors, including among others parental control over the board of directors, instructions imposed on the subsidiary to be carried out, the amount of profit taken by the parent and other elements referring to real decisive influence by a parent over its subsidiary. ${ }^{137}$ The exact weight attributed to either ownership, non-ownership control or additional conduct factors has been the subject of intense discussions and divergent interpretations.

The interrelations between control and conduct are most apparent in the case law on the single entity status of hybrid affiliations involved in distribution, commercial agency and other intermediary agreements. ${ }^{138}$ Commercial agency agreements potentially benefit from single

\footnotetext{
${ }^{134}$ See case 22/71, Béguelin Import Co. v S.A.G.L. Import Export [1971] ECR 949, para. 8. See also W. Wils, note 1 above, 112 .

135 See Bodson note 119 above, para. 19; CFI T-9/99, HFB Holding für Fernwärmetechnik Beteiligungsgesellschaft $\mathrm{mbH} \& \mathrm{Co}$. KG and Others v Commission of the European Communities [2002] ECR II-1487, para. 66; Case T-66/99 Minoan Lines SA v Commission of the European Communities [2003] ECR II5515, para. 123; Case T-325/01, DaimlerChrysler AG v Commission of the European Communities [2005] ECR II-3319, para. 85; J. Briggs and S. Jordan, 'Developments in the law: the presumption of shareholder liability and the implications for shareholders in private damages actions and otherwise', Global competition litigation review 2009, 2(4), (203) 203-204;A. Jones and B. Sufrin, note 121 above, 134-135; A. Riesenkampf and U. Krauthausen, note 5 above, 41

${ }^{136}$ Case 48/69, Imperial Chemical Industries Ltd. $v$ Commission of the European Communities [1972] ECR 619, para. 134; Case 15/74 Centrafarm BV et Adriaan de Peijper v Sterling Drug Inc. [1974] ECR 1147, para. 41; Bodson note 119 above, para. 4; Case 66/86, Ahmed Saeed Flugreisen and Silver Line Reisebüro GmbH v Zentrale zur Bekämpfung unlauteren Wettbewerbs e.V. [1989] ECR 803, para. 35; G. Assant, note 2 above, 68; L. Ritter and W. Braun, note 119 above, 46-48

${ }^{137}$ Case 107/82, Allgemeine Elektrizitäts-Gesellschaft AEG-Telefunken AG $v$ Commission of the European Communities [1983] ECR 3151, para. 50-52; Case C-286/98 P, Stora Kopparbergs Berlgslags AB v. Commission [2000] ECR I-9925, para. 21-30; Case T-314/01, Coöperatieve Verkoop- en Productievereniging van Aardappelmeel en Derivaten Avebe BA v Commission of the European Communities [2006] ECR II-3085, para. 135-142; A. Jones and B. Sufrin, note 121 above, 137; L. La Rocca, note 5 above, 73-74

${ }^{138}$ Scholars distinguished acquired undertakings, groups of undertakings and controlling undertakings, the latter including both parent - subsidiary and alternative control arrangements, see A. Montesa and A. Givaja, note 3 above, 559-560.
} 
entity immunity, as the conduct of 'independent' commercial agents ${ }^{139}$ is often quite dependent on instructions received from a principal. ${ }^{140}$ In the pilot case of Suiker-Unie ${ }^{141}$, the ECJ affirmed what already had been established in earlier decisions of the European Commission. ${ }^{142}$ It stated that 'if an agent works for the benefit of his principal he may in principle be treated as an auxiliary organ forming an integral part of the latter's undertaking, who must carry out his principal's instructions and thus, like a commercial employee, forms an economic unit with this undertaking'. ${ }^{143}$ The Court of Justice presented a two-step test relying on market conduct in order to verify the degree of autonomy of the agent. First the agent may not bear any financial risk. Second, the agent may not engage in activities of both agent and independent trader in respect of the same market. ${ }^{144}$ In the Suiker-Unie case the ECJ decided that article 101 TFEU was applicable since ' $(.$.$) it is not disputed that the agents$ in question are large business houses, which at the same time as they distribute sugar for the account of the applicant, (...) undertake a very considerable amount of business for their own on the sugar mark ${ }^{145}(\ldots)$ Thus these representatives are authorized to act as independent dealer ${ }^{146}(\ldots)$ The integration of representatives in its sales organization 'did not rule out the possibility that agents may also compete with independent dealers, in particular when they sell for their own account (...)' ${ }^{147}$

The Court subsequently extended this reasoning to wholly owned subsidiaries. In the important Viho case ${ }^{148}$, Parker Pen Ltd. sold its products through wholly owned subsidiaries

\footnotetext{
${ }^{139}$ The definition of commercial agency agreements: «they cover the situation in which a legal or physical person (the agent) is vested with the power to negotiate and/or conclude contracts on behalf of another person (the principal), either in the agent's own name, or in the name of the principal for the purchase of goods or services by the principal or the sale of goods or services supplied by the principal» (see Commission Notice on Guidelines on Vertical Restraints, OJ C 230/1, 19 May 2010, para. 12)

${ }_{140}$ Case 311/85, ASBL Vereniging van Vlaamse Reisbureaus v ASBL Sociale Dienst van de Plaatselijke en Gewestelijke Overheidsdiensten [1987] ECR 3801, para. 20; Case C-266/93 Bundeskartellamt v Volkswagen AG and VAG Leasing GmbH. [1995] ECR I-3477, para. 19; Case T-66/99 Minoan Lines SA v Commission of the European Communities [2003] ECR II- 5515, para. 125; Case T-325/01 Daimler Chrysler AG v Commission of the European Communities [2005] ECR, II- 3319, para. 86; Case C-217/05 Confederación Española de Empresarios de Estaciones de Servicio v Compañía Española de Petróleos SA [2006] ECR I-11987, para. 42; I. Lianos, 'Commercial agency agreements, vertical restraints, and the limits of Article 81(1) EC: between hierarchies and networks', J.C.L. \& E.2007, 3 (4), (625) 628; A. Jones and B. Sufrin, note 121 above, 2011, 135.

${ }_{141}$ Joined cases 40 to 48,50,54 to 56,111, 113 and 114/73, Coöperatieve Vereniging "Suiker Unie" UA and others v Commission of the European Communities [1975] ECR 1663 (hereafter referred to as Suiker Unie).

${ }^{142}$ Commission, Pittsburgh Corning Europe O.J. 1972 L 272/35; I. Lianos, note 140 above, 632.

${ }^{143}$ Suiker Unie, note 141 above, para. 480.

${ }^{144}$ I. Lianos, note 140 above, 633.

${ }^{145}$ Suiker Unie, note 141 above, para. 544.

${ }^{146}$ Suiker Unie, note 141 above, para. 546.

${ }^{147}$ Suiker Unie note 141 above, para. 547.

${ }^{148}$ Case C-73/95 P, Viho Europe BV v Commission of the European Communities [1996] ECR I-5457 (hereafter referred to as Viho).
} 
in various member states. In so doing, the parent company divided the common market into national markets between its subsidiaries. The ECJ, following the General Court's approach, did not consider Article 101 applicable in this context. According to the court, 'where, as in this case, the subsidiary, although having a separate legal personality, does not freely determine its conduct on the market but carries out the instructions given to it directly or indirectly by the parent company by which it is wholly controlled, Article [101] does not apply to the relationship between the subsidiary and the parent company with which it forms an economic unit'. ${ }^{149}$ The distribution subsidiaries did not enjoy real autonomy in determining their course of action in the market, as they merely had to carry out the instructions of the controlling parent company. ${ }^{150}$

Suiker Unie and Viho present an EU single entity test relying on control and conduct. Whereas Suiker Unie presumes non-ownership based control, Viho distinguishes elements of ownership-based control (intra-enterprise behaviour or potentially decisive influence) and market conduct (extra-enterprise behaviour or actual decisive influence ${ }^{151}$ ) as two fundamental variables to establish single entity claims in EU law. ${ }^{152}$ Neither Suiker Unie nor Viho did establish a clear hierarchy among these elements. The degree to which ownership based control, alternative control elements or specific market conduct determine single entity claims remains unclear.

The ECJ also considered whether or not employee agreements could be captured by Article 101. Again, it relied on similar elements of control and conduct to assess single entity claims. Competition law may apply to a natural person who constitutes an undertaking in accordance with article 101 TFEU when acting independently. ${ }^{153}$ However in the Albany case the Advocate General argued that this was not the case when an individual acts as an employee on the economic market. 'First, it is difficult to see how the term 'undertaking' could be understood in the sense of 'employee'. (...)Secondly, the functional interpretation of the term 'undertaking' which the Court has adopted in its case-law leads to the same result (...) thirdly, the system of Community competition law is not tailored to be applicable to employees'. ${ }^{154}$

\footnotetext{
${ }^{149}$ Viho, note 148 above, para. 6.

${ }^{150}$ Viho, note 148 above, para 16.

151 At the very least, the subordinate (subsidiary or affiliated corporation or employee) should itself enjoy no market autonomy at all, A. Montesa and A. Givaja, note 3 above, 560.

${ }^{152}$ See in that respect mainly K. Hofstetter and M. Ludescher, note 5 above, 58.

${ }_{153}$ A. Jones and B. Sufrin, note 121 above, 134; L. Ritter and W. Braun, note 119 above, 45.

${ }^{154}$ Opinion of AG Jacobs in Albany, note 131 above, para. 213-216.
} 
Since an employee cannot act independently from the undertaking, he or she is incorporated in the undertaking. The undertaking therefore comprises an economic unit with each employee. $^{155}$

In determining if an individual acts independently or as an employee, the ECJ again takes into account whether or not the individual bears the direct commercial risk of the transaction ${ }^{156}$, whether they are subject to orders from their employer and whether they offer services and goods to different clients or work for one single employer. ${ }^{157}$ The ECJ decided that custom agents constitute undertakings since 'they offer, for payment services consisting in the carrying out of customs formalities, (...)as well as complementary services (...) Furthermore, they assume the financial risks involved in the exercise of that activity'. ${ }^{158}$ The Court also applied these constituent factors in later cases. Registered members of the Bar Association (self-employed lawyers) are undertakings, ${ }^{159}$ as are self-employed medical specialists. ${ }^{160}$ Dock workers have an employment relationship with the undertakings for which they perform dock work as they work for and under the direction of each of those undertakings. ${ }^{161}$

\subsection{Single entity prosecution and parent company liability}

In addition to providing a shield against applying EU competition rules, single entity claims have more recently been rediscovered as swords to extend the scope of enforcement of these rules. ${ }^{162}$ In so doing, similar criteria also relied on to exclude single entities from the scope of competition law have resurfaced to ensure a more inclusive entity subject to competition law fines. The prosecutorial perspective provides fundamental insights into how the ECJ operationalizes or could further operationalize the weight attached to ownership, control and conduct requirements in a general EU single entity test.

\footnotetext{
${ }^{155}$ Case C-22/98, Веси [1999] ECR I-5665, para. 26 (hereafter referred to as Becu); N. Brunn and J. Helsten, Collective agreement and competition law in the EU : the report of the COLCOM-project, Kopenhagen, DjØf, 2001, 12, n⿳⺈ 18; P. Nihoul, supra note 119, 413.

${ }^{156}$ This idea is derived from Suiker Unie, note 141 above, para. 541 where the ECJ decided that an agent is an undertaking when he accepts the financial risks; O. Odudu, "Economic activity as a limit to community law" in C. Barnard and O. Odudu (eds), The outer limits of the European Union law, (Oxford, Hart, 2009), 240.

${ }^{157}$ Opinion of AG Jacobs in Albany, note 131 above, para. 215; O. Odudu, note 156 above, 240.

${ }^{158}$ Case C-35/96, Commission of the European Communities v Italian Republic [1998] ECR, I-3851, para. 37.

${ }^{159}$ Case C-309/99, Wouters, note 124 above, para. 49.

160 Joined cases C-180/98 to C-184/98, Pavel Pavlov and Others v Stichting Pensioenfonds Medische Specialisten [2000] ECR I-6451, para. 111.

${ }^{161}$ Becu, note 155 above, para. 26.

${ }^{162}$ On the particular combination of prosecutorial and adjudicative rules, see W. Wils, 'The Combination of the Investigative and Prosecutorial Function and the Adjudicative Function in EC Antitrust Enforcement: A Legal and Economic Analysis', W.Comp.27 (2004), 201-224.
} 
The ECJ established that infringements committed by subsidiaries could be attributed to the parent company or to other "related" companies ${ }^{163}$, to the extent that the latter exercise direct or actual influence over the subsidiary's decisionmaking practices. ${ }^{164}$ In those instances, an undertaking will often be held to have engaged in restrictive practices with another undertaking, represented by a subsidiary corporate entity. Parent companies can thus be held liable for restrictive practices engaged in by subsidiaries.

The conditions for attributing competition law infringements to parent companies - and thus to establish single entity status -rely on control and market conduct variables. According to the ECJ, 'the fact that a subsidiary has separate legal personality is not sufficient to exclude the possibility of its conduct being imputed to the parent company, especially where the subsidiary does not independently decide its own conduct on the market, but carries out, in all material respects, the instructions given to it by the parent company'. ${ }^{165}$ The ability to influence market conduct is in the first place assessed in light of present control rights, rather than the actual exercise of control as such. ${ }^{166}$ In that respect, particular attention is paid to 'the economic, organisational and legal links between [different] legal entities'. ${ }^{167}$ The concept of control nevertheless presents operational difficulties in determining a correct standard to assess whether or not economic, legal or organizational links are sufficient. With a view to operationalize control, the Courts have regularly relied on ownership presumptions to substantiate corporate control claims.

\footnotetext{
${ }^{163}$ In C-196/99, Aristrain, the ECJ debunked the claim that sister corporate legal entities should always be considered part of a single entity because they are controlled by the same person, see text accompanying footnote 183 .

164 Case C-97/08 P Akzo Nobel NV and Others v Commission of the European Communities [2009] ECR I8237, para. 59 (hereafter referred to as Akzo); L. La Rocca, note 5 above, 71; L. Ritter and W. Braun, note 119 above, 48. For earlier cases along the same lines, see among others Case 48/69, Imperial Chemical Industries Ltd. v Commission of the European Communities [1972] ECR 619, para. 135; Case 107/82, Allgemeine Elektrizitäts-Gesellschaft AEG-Telefunken AG v Commission of the European Communities [1983] ECR 3151, para. 49; Case T-77/92, Parker Pen Ltd v Commission of the European Communities [1994] ECR, II-549, para. 57; Case T-9/99, HFB Holding für Fernwärmetechnik Beteiligungsgesellschaft mbH \& Co. KG and Others $v$ Commission of the European Communities [2002] ECR II-1487, para. 66; Case T-66/99 Minoan Lines SA v Commission of the European Communities [2003] ECR II-5515, para. 123.

165 Akzo, note 164 above, para. 58, referring to established case law. Case T-354/94, Stora Kopparbergs Bergslags AB v Commission of the European Communities, [1998] ECR II-2111, para 79 (hereafter referred to as Stora).

${ }^{166}$ Wils, note 2 above, 106-107, referring to the undertaking concept in mergers as well.

167 Akzo, note 164 above, para 58. A wide conception of these links could be incorporated in a Commission mindset based on prosecuting. That prosecutorial bias would allow competition authorities to engage more easily in establishing single entity status. On prosecutorial bias in EU competition law, see W. Wils, note 162 above, 212-217.
} 
In Akzo, the ECJ held that 'in the specific case where a parent company has a $100 \%$ shareholding in a subsidiary which has infringed the Community competition rules, first, the parent company can exercise a decisive influence over the conduct of the subsidiary and, second, there is a rebuttable presumption that the parent company does in fact exercise a decisive influence over the conduct of its subsidiary' ${ }^{168}$ Full ownership does not only presume corporate control, it also presumes decisive market conduct influence. ${ }^{169}$ The fact that other circumstances had been taken into account in earlier case law ${ }^{170}$, does not however make the application of the presumption 'subject to the production of additional indicia relating to the actual exercise of influence by the parent company'. ${ }^{171}$

Akzo is particularly controversial because the ECJ took sides in a debate that included two approaches to single entity prosecution. ${ }^{172}$ The first approach entailed a full blown (belts and braces) inquiry of single entity, requiring the European Commission to establish both control and conduct parameters being fulfilled in order to attribute anticompetitive conduct to a parent company. The second approach requires the Commission merely to establish control and imposes the entire burden of proof on the defendant parent company to establish its nonsingle entity status. ${ }^{173}$ It requires the parent company to establish that it did not influence the subsidiary's conduct or did not fully control the subsidiary's decision making process.

The burden of proving the absence of influence on conduct or lack of control has generated controversy, as two readings can be adduced to rebut a presumption of single entity based on parenthood. According to the General Court and confirmed on appeal by the Court of Justice, the parent company should establish that it was not 'able to influence pricing policy production and distribution activities, sales objectives, gross margins, sales costs, cash flow,

\footnotetext{
${ }^{168}$ Akzo, note 164 above, para 60

169 Akzo, note 164 above, para. 63.

${ }^{170}$ Case 22/71, Béguelin Import Co. v S.A.G.L. Import Export [1971] ECR 949, para. 8; Case 107/82, Allgemeine Elektrizitäts-Gesellschaft AEG-Telefunken AG v Commission of the European Communities. [1983] ECR 3151, para. 50; Stora, note 165 above, para. 29; Akzo, note 164 above, para. 60; J. Briggs and S. Jordan, note 135 above, 204; L. La Rocca, note 5 above, 68.

${ }^{171}$ Akzo, note 164 above, para 62.

${ }^{172}$ For more details and particular difficulties related to this case, see L. La Rocca, note 5 above, 73-76.

173 The belts and braces approach was long adhered to by the General Court, see T-109/02, Bolloré e.a. v. Commission, [2007] ECR II-947, para. 132; T-69/04, Schunk v. Commission, [2008] ECR, II-2567, para. 57; T301/04, Clearstream Banking en Clearstream International v. Commission, [ 2009] ECR II-3155, para. 199-200; T-112/05, Akzo Nobel e.a. v. Commission, [2007] ECR II-5049, para. 60. For background, see A. Riesenkampf and U. Krauthausen, note 5 above, 38-41; L. La Rocca, note 5 above, 70-72.
} 
stocks and marketing, ${ }^{174}$ A parent could thus rebut single entity presumptions by demonstrating that it did not influence the subsidiary's market bevaviour in its specific niche of operations. At the same time, the ECJ in Akzo held that parent companies could also bring forward alternative relevant factors. These factors relate to all economic, organizational or legal links established between subsidiary and parent. ${ }^{175}$ Scholars have read that requirement to impose on parent companies the burden to establish lack of management influence on the conduct of the subsidiary in general and not merely on the market related to competition law infringements. ${ }^{176}$ More specifically, it would require a parent company to establish that it did not have control over the subsidiary's operations, which would in practice be impossible to achieve, because a parent - subsidiary relationship precisely by nature implies some level of control. ${ }^{177}$ We do however read the ECJ's 'all elements' requirements in a more nuanced way. According to that reading, the ECJ meant to hold that its presumption of single entity could be rebutted by both evidence related to control and to conduct. It does not however hold that claims solely based on either control or conduct are insufficient to rebut the Akzo presumption. In line with the Advocate General, 'the decisive factor is whether the parent company, by reason of the intensity of its influence, can direct the conduct of its subsidiary to such an extent that the two must be regarded as one economic unit'. ${ }^{178}$ The ECJ merely provided a basis for a single entity test based on interacting control and conduct variables. To the extent that a presumption of control has been established, lack of influence on particular conduct could still remain sufficient evidence to rebut single entity claims. The extent to which that is the case does however remain unclear from the Court's judgment in Akzo.

\subsection{The EU single entity test}

Control and conduct are crucial components of the judicially established EU single entity test, even though their interaction or cumulative application remains unclear in many instances. ${ }^{179}$ Notions of (corporate) control are crucial in establishing a single entity. The ECJ clearly

\footnotetext{
174 Akzo, note 164 above, para. 64, with references made to the CFI Viho judgment (CFI, T-102/92 Viho v Commission [1995] ECR II-17, paragraph 48).

${ }_{175}$ Akzo, note 164 above, para. 65.

${ }^{176}$ L. La Rocca, note 5 above, 73; F. Wenner and B. Van Barlingen, "European Court of Justice confrims Commission's approach on parental liability", Competition Policy Newsletter 2010, 26-27: What matters is the overall distribution of responsibilities within the group.

${ }^{177}$ K. Hofstetter and M. Ludescher, note 5 above, 60; A. Montesa and A. Givaja, , note 3 above, 566.

178 Opinion of Advocate General Kokott in Akzo, note 164 above, para 93.

${ }^{179}$ See already W. Wils, note 2 above, 107.
} 
mentions control to be an important element of single entity discourse. ${ }^{180}$ Not unlike U.S. law, control is operationalized through affirmative and negative control rights. Control at first sight firmly relates to ownership rights ${ }^{181}$, but as the Court itself makes clear in relation to commercial agents, control does not need to imply ownership. ${ }^{182}$ In non-ownership cases, the courts appear willing to draw inferences from commercial or financial risk and other factors. In all instances however, control rights appear sufficient to pass the first single entity hurdle. Control rights have to be direct: the mere presence of a single parent company of two sister companies cannot suffice to infer elements of control among sister companies' interactions. ${ }^{183}$ Direct control rights therefore often presuppose a vertical relationship, whether ownership based or not.

In addition to control, integrated market conduct comprises a second step in establishing a single entity test. As mentioned above, the scope of market conduct could be assessed either in general or in the specific market related to the competition law infringement at stake. "Market conduct" assesses whether a subsidiary or controlled entity is able to determine its own policies and actions on the market or the actual freedom it has been granted to operate in a particular market segment. ${ }^{184}$ To the extent it cannot do either, the controlled entity is presumed to constitute a single undertaking with the controlling entity. ${ }^{185}$ From a

\footnotetext{
${ }^{180}$ One could even argue that the ECJ is more direct here than the US Supreme Court in American Needle. The US Supreme Court only discussed control in the margin of its independent centers of decisionmaking condition in American Needle. Read in conjunction with Copperweld however, one could (and in our opinion, should) argue that control is crucial in the U.S. single entity's test as well. As part two highlighted, control remains the most fundamental proxy for assessing the independence of decisionmaking centers.

${ }^{181}$ At least in cases concerning parent company liability, but see T. Feaster and P. Treacy, 'When two into one will go: intra-group agreements and Article 85(1)', E.L.Rev. 27 (1997), 576 for a perspective on 'single entity defenses'.

${ }^{182}$ According to A. Montesa and A. Givaja, , note 3 above, 571, a parent company may 'exercise' its power to influence the subsidiary by putting in place appropriate management/controlling mechanisms allowing it to control the subsidiary's market conduct in general, that is to say, at least with regard to its main strategic plans. This mechanism could take the form of (a) management teams appointed by the parent company to control the subsidiary as in Viho; or (b) the adoption of a coordination role by the parent company reinforced by the presence of documents containing express orders for organizing meetings to formulate marketing and pricing policies as in Shell.

${ }^{183}$ Case C-196/99 P, Siderúrgica Aristrain Madrid SL v. European Commission, [2003] ECR I-1105, para. 99: The simple fact that the share capital of two separate commercial companies is held by the same person or the same family is insufficient, in itself, to establish that those two companies are an economic unit with the result that, under Community competition law, the actions of one company can be attributed to the other and that one can be held liable to pay a fine for the other.

${ }^{184}$ French competition law case law made an additional distinction: to the extent that related corporate entities hold themselves out as separate competitors, their conduct is not integrated and they therefore do not present a single economic entity. See M. Thill-Tayara, "Holding on to the "holding out doctrine": the French approach towards intra-group conspiracy', ECLR 24 (2003), 553-556. This finding goes against P. Areeda's argument that in U.S. antitrust law, holding out should not be a ground for conspiracy attribution, see P. Areeda, note 39 above, 468

${ }^{185}$ See among others R. Burnley, note 4 above, 610.
} 
prosecutorial standpoint, a controlling entity can rebut the presumption(s) of single entity by claiming that it presents an actual or potential market competitor. ${ }^{186}$ From a defensive point of view, parties to the proceedings are required to demonstrate that an entity does not determine its own commercial policy or acts in other ways as a controlled and non-competing entity. According to the Commission, a parent or otherwise controlling company has to adduce precise explanations regarding its relationship with controlled entities. Mere general assertions of lack of control or influence on conduct do not suffice. ${ }^{187}$ The EU's framework can be presented in the following way:

Table 2: EU Single Entity testing framework

\begin{tabular}{|c|c|c|c|}
\hline $\begin{array}{l}\text { Decisive influence } \\
\text { test }\end{array}$ & $\begin{array}{l}\text { Wholly owned } \\
\text { subsidiary (Akzo) }\end{array}$ & Hybrid affiliations 1 & Hybrid affiliations 2 \\
\hline Control rights & $\begin{array}{l}\text { Rebuttable } \\
\text { presumption of } \\
\text { decisive influence }\end{array}$ & $\begin{array}{l}\text { Rebuttable } \\
\text { presumption of } \\
\text { decisive influence if } \\
\text { significant (direct) } \\
\text { ownership rights }\end{array}$ & $\begin{array}{l}\text { Rebuttable } \\
\text { presumption of } \\
\text { decisive influence if } \\
\text { alternative control } \\
\text { rights? }\end{array}$ \\
\hline $\begin{array}{l}\text { Integrated market } \\
\text { Conduct }\end{array}$ & $\begin{array}{l}\text { Rebuttable } \\
\text { presumption }\end{array}$ & $\begin{array}{l}\text { Rebuttable } \\
\text { presumption? } \\
\text { Independent conduct } \\
\text { determination: } \\
\text { analysis of interests } \\
\text { and potential } \\
\text { competitiveness }\end{array}$ & $\begin{array}{l}\text { Independent conduct } \\
\text { determination: } \\
\text { analysis of interests } \\
\text { and potential } \\
\text { competitiveness }\end{array}$ \\
\hline
\end{tabular}

Control rights and market conduct present themselves as operational conditions to establish or rebut single entity status, but their exact interaction and the weight attributed to each of them is unclear. To the extent that evidence of ownership rights can be established - and perhaps even if control is established without direct or significant references to ownership rights, a presumption of integrated market conduct could help both prosecutorial and defensive single

\footnotetext{
${ }^{186}$ Proposals related to best practice guidelines compliance have been developed in that regard, holding that a parent company should not be held liable if the parent company complies with particular best practices related to monitoring or supervising the entity. See K. Hofstetter and M. Ludescher, note 5 above, 65-66. Other proposals have approached these issues from a 'defensive' perspective, see e.g. T. Feaster and P. Treacy, note 181 above, 576.

${ }^{187}$ A. Montesa and A. Givaja, , note 3 above, 572.
} 
entity pleas. "Integrated market conduct" is equally difficult to operationalize. The concept contains elements of both entrepreneurial interests and actual or potential competition that appear U.S. law. Whereas the U.S. single entity test is not entirely clear either, it at least proposes a more nuanced distinction among different arguments, the weight of which is uncertain in a general integrated market conduct structure. A full-fledged entrepreneurial interest and competitive link test would therefore be more helpful to assess whether two controlled entities do not engage in restrictive practices through integrated market conduct. So far however, the conduct stage of the EU's test remains vague and hardly predictable on a more general level.

\section{Concluding remarks: prospects for single entity convergence?}

The previous sections juxtaposed single entity claims as a matter of competition law in the U.S. and the EU. We analyzed how courts in particular developed, explicated or presumed the existence of single entities to define the scope of competition law. EU law debates have mainly focused on the scope of application or on the prosecutorial dimension of single entity, whereas U.S. case law has aimed to integrate single entity analysis more directly into debates on the nature of restraints to competition. Following American Needle, the idea of a per se rule of single entity has been replaced by a set of (quick look) rebuttable presumptions, similar to the approach taken in the EU for much longer. In addition, the EU's recent prosecutorial focus of single entity debates allows to explicate the foundations and conditions of single entity in relation to parent - subsidiary relationships and thereby allows more analytical clarity in devising an EU single entity test. Emphasis on control and conduct in both legal orders allows for a more dynamic and economically oriented inquiry into the scope of competition law provisions.

Our aim in this concluding section is not to develop one single transatlantic 'single entity' test. A workable test defines the necessary and sufficient operational conditions under which business behaviour is illegal and assigns the burden of proof. ${ }^{188}$ These elements necessarily relate to particular procedural and evidentiary aspects of a legal system. Claims to design a common transatlantic test would therefore disregard particularities that function as the very variables of that test in these jurisdictions. Rather than developing a single test, the abovementioned juxtaposition of single entity claims in both legal systems nevertheless

188 D. Evans, 'How Economists Can Help Courts Design Competition Rules: An EU and US Perspective', W.Comp 28 (2005), 93. 
allows us to develop three reasons as to why further convergence among EU and U.S. single entity claims would significantly benefit both legal orders.

First, both EU and U.S. single entity tests are grounded in a general theoretical framework of the firm in which control is primarily - but not necessarily - related to ownership and in which market conduct presents an important additional variable. Judges' willingness to assess the role attributed to a variety of control rights appears to underlie the scope of both tests. On the one hand, both EU and U.S. single entity claims rely on particular notions of control and market conduct. The uncertainty and vagueness of any conception of control is apparent in both legal regimes. In both systems, specific cases have translated the notion of control into control rights based on ownership presumptions, but have left open alternative control arrangements to be included in a single entity test. As such, non-ownership related control mechanisms would not appear to be inherently excluded from (potential) single entity tests in either legal order. On the other, market conduct has been further subdivided into entrepreneurial interests and the absence of an actual or potential competitive link in U.S. law and could thus provide a more nuanced testing framework for EU law. In addition, the law in both systems now attributes (rebuttable) presumptions of integrated market conduct to wholly owned subsidiaries and potentially extends that approach to less than wholly owned entities. Both tests thus present comparable variables and a comparable framework for judicial developments in this field.

Second, the establishment of a single entity test in both legal orders remains a matter of judicial lawmaking. In both regimes, a supreme court has the final say on the scope and existence of single entity claims. Even though the European Commission can adopt binding decisions and impose fines as a matter of EU law, its activities are subject to judicial review. In the end however, the Commission has to take stock of the ECJ's case law on the matter. The U.S. remedial mechanisms almost exclusively relies on court decisions. In the same way, the U.S. Supreme Court has the final say on legal matters, thus allowing both institutions to develop a single entity test. Convergence could thus significantly be facilitated as the scope of potential convergence actors can be relegated to two courts already regularly interacting with one another. ${ }^{189}$

\footnotetext{
${ }^{189}$ On judicial convergence among the U.S. Supreme Court and the European Court of Justice, F. Jacobs,
} 'Judicial Dialogue and the Cross-Fertilization of Legal Systems: The European Court of Justice', Texas 
Third, both legal tests showcase sufficiently different nuances, allowing for beneficial mutual enrichment among EU and U.S. lawyers. The ECJ's more direct reliance on corporate control, rather than on 'absence of separate decision making' centers provides more certainty in delineating a single entity framework. The operationalization of market conduct in interests and specific or general market behaviour proves relevant for EU lawyers to consider. At the same time, issues related to the scope of 'absence of actual or potential competition' or of integrated market conduct raise similar questions and demand more attention to market definition questions in developing a fully operational single entity test. The scope of that inquiry potentially defines the scope of single entity claims and the ensuing policies underlying competition law application and enforcement. Finding a generally acceptable operational standard in either legal regime might benefit from the analysis of arguments elaborated in the other.

The abovementioned reasons indicate that single entity convergence does not remain a distant theoretical possibility. As tools for convergence, elements of control and conduct allow to refine and substitute current testing frameworks by more detailed structures. More detailed and focused interactions among practitioners, scholars and policymakers are necessary to generate true convergence. At the very least, the antitrust mindsets on both sides of the Atlantic Ocean have been imbued by thinking in terms of operational conditions and finding a workable single entity testing framework. It is now up to judges and practitioners to operationalize that framework into more predictable and concrete single entity tests. As this contribution aimed to demonstrate, analyzing U.S. antitrust or EU competition law as an inspiration for gap filling can contribute to these operationalization efforts. 